\title{
"The Present Value Relation Over Six Centuries: The Case of the Bazacle Company"
}

\author{
David le Bris, William N. Goetzmann \\ and Sébastien Pouget
}




\title{
The Present Value Relation Over Six Centuries:
}

\section{The Case of the Bazacle Company*}

\author{
David le Brisł William N. Goetzmann; and Sébastien Pouget $\S$
}

April 7, 2017

\footnotetext{
${ }^{*}$ We would like to thank Vikas Agarwal, Bruno Biais, Chloé Bonnet, Claude Denjean, René Garcia, José Miguel Gaspar, Alex Guembel, Pierre-Cyrille Hautcœur, Christian Julliard, Augustin Landier, Laurence Lescourret, Junye Li, Patrice Poncet, Jean-Laurent Rosenthal, Steve Ross, Sandrine Victor, Maxime Wavasseur and especially Marianne Andries, Ralph Koijen and Nour Meddahi, as well as seminar and conference participants at the Toulouse School of Economics, the CIFAR-IAST conference, UC Irvine, HEC, ESSEC, Georgia State University, Casa de Velazquez - Madrid, and the AEA meeting 2016 for helpful comments and suggestions. We also wish to thank Geneviève Douillard and Daniel Rigaud, from the Archives Départementales de la Haute-Garonne, for their help in finding and reading original documents.

${ }^{\dagger}$ University of Toulouse, Toulouse Business School

${ }^{\ddagger}$ Yale School of Management, Yale University

$\S$ Toulouse School of Economics, University of Toulouse Capitole (IAE, CRM)
} 


\title{
The Present Value Relation Over Six Centuries: The Case of the Bazacle Company
}

\begin{abstract}
We study asset pricing over the longue durée using share prices and net dividends from the Bazacle company of Toulouse, the earliest documented shareholding corporation. The data extend from the firm's foundation in 1372 to its nationalization in 1946. We find an average dividend yield of $5 \%$ per annum and near-zero long-term, real capital appreciation. Stationary dividends and stock prices enable us to directly study how prices relate to expected cash flows, without relying on a rate of return transformation. A reduced-form asset pricing model with persistent dividends and a time-varying risk correction is not rejected by the data.
\end{abstract}

Keywords: asset pricing, history of finance, present-value tests. 


\section{The Present Value Relation Over Six Centuries: \\ The Case of the Bazacle Company}

\section{Introduction}

The present value relation is fundamental to economics and finance. It provides an analytical framework for asset valuation and the calculation of discount rates. It serves as a benchmark for assessing market efficiency and the process by which economic agents form and use expectations about the future.

Testing the present value relation for traded financial securities like stocks and bonds has presented some challenges because of the role played by expectations and time-varying correction for risk. While it is simple to state that the present value of an asset should be equal to the expected discounted future value of the benefits it confers to its owner, the process by which expectations are formed and maintained must naturally be quite broad and complex because it must incorporate an entire future world of possibilities. Moreover, the appropriate level of price adjustment to account for risk is, in general, unobservable.

In this paper, we use the unique experience of an extraordinarily long-lived company as a laboratory to test the present value relation. ${ }^{1}$ This company, called the Honor del Bazacle, was created in Toulouse in 1372 to operate watermills. Shares of the company were owned and regularly traded by individuals and institutions over the course of its history. Following its conversion to a hydroelectric generating company in 1888, the company listed on the Paris Stock Exchange and traded there until nationalization in 1946. We hand collected share price and dividend data over a nearly five-century period during which the company

\footnotetext{
${ }^{1}$ Using long time-series in financial economics has proved fruitful as illustrated for example by the studies of Schwert (1990), Goetzmann (1993), Homer and Sylla (2005), Goetzmann and Ibbotson (2006), Siegel (2007), Dimson, Marsh, and Staunton(2008), le Bris and Hautcour (2010), Chabot and Kurz (2010), Dimson and Spaenjers (2011), Reinhart and Rogoff (2014), Annaert, Buelens, and Deloof (2014), and Golez and Koudijs (2016).
} 
operated, and integrated it with previously collected data up to 1450 . The result is an economic record of a corporate enterprise that extends from the Middle Ages to modern times.

This dataset offers a particularly suitable testbed for asset pricing theory for four key reasons. First, it extends over a long period of time without major technological or governance changes. The Bazacle company's dividends reflect a stable fundamental economic process that was presumably well understood by investors thanks to at least two centuries of milling business that pre-dated the creation of the firm in 1372. Innovation in mill technology was slow before the late 19th century. A significant part of the sample period precedes the Industrial Revolution and the modern period of high GDP growth by Western economies. Uncertainty about growth due to technological change likely played a minor role in the expectations process in our data whereas it was likely an important factor in most studies relying on data from the 20 th and 21 st centuries.

Second, the long time period includes rare economic disasters of great magnitude. Recent asset pricing literature highlights the potentially important role that expectations about rare disasters play in the equity risk premium (see for example, Rietz (1988), Barro (2006), and Julliard and Gosh, (2012)). Our sample ranges over centuries and includes events such as major wars, plague, serious famine and devastating floods. We are thus able to examine the effect of these shocks on the present value relation and the equity risk premium.

Third, the real dividends and stock prices of the Bazacle company are stationary. Stationarity allows us to explicitly study the link between the absolute level of stock prices and the absolute level of expected dividends. This link is seldom examined in the asset pricing literature because stock prices in recent periods are not stationary. ${ }^{2}$ This feature is particularly important because it enables a test of a permanent mispricing in levels, which is not

\footnotetext{
${ }^{2}$ In this respect, our study thus complements experimental analyses such as Crockett and Duffy (2016) and Asparouhova, Bossaerts, Roy, and Zame (2016).
} 
possible when using rates of return and dividend growth rates (West, 1988). ${ }^{3}$

Fourth, unlike modern corporations, the Bazacle company maintained a policy for most of its existence of paying out all profits each year as dividends. This peculiar feature allows us to estimate an asset pricing model without the confounding effects of dividend smoothing. Management-smoothed earnings and dividends are a complicated inter-temporal function that can mask information embedded in the raw economic dividend process. This is a challenge for most empirical analyses that rely on modern dividend and earnings measures.

Figure 1 provides an introduction to our data and a glimpse at the present value relation. In the spirit of Shiller (1981), we plot the actual stock price and the present value of the subsequent realized dividends discounted at a fixed rate of $5 \%$. Note that, contrary to Shiller (1981), the Figure is based on raw data without de-trending or an assumption regarding the terminal value (dividends were essentially null after the 1946 nationalization). ${ }^{4}$

\section{[Insert Figure 1 here]}

There are three main insights from this figure. First, the average level of observed stock prices is stationary, as is the discounted future dividend series. Second, the variations in the prices over time track the variations in the discounted future dividends quite well. Third, visual inspection of our data suggests that there is no persistent mispricing. Overall, Figure 1 suggests that stock prices over the long history of the company may actually be economic expectations of future dividends.

\footnotetext{
${ }^{3}$ Given that net payouts to shareholders are sometimes negative in our data, the classical way of making stock prices and dividends stationary, which consists in computing first differences or in studying the dividend price ratio, would not be appropriate.

${ }^{4}$ In Figure 1, stock prices begin in 1372. The present value of subsequent realized dividends is computed from 1441 onward, the first year in which we have both a stock price and a dividend. For a given year after 1441, a missing dividend is replaced by the average dividend over the past 30 years. At the end of the period, we assume that dividends are null even if, in fact, after the 1946 nationalization, investors received a few, small, residual payments. We chose the rate of $5 \%$ because it corresponds to the legal rate of interest both under the Roman law applicable up to the French Revolution, and under the Napoleonic civil code.
} 
Elaborating on Shiller (1981), one could compute the implied discount rate that is necessary, at each date, to equalize the observed price and the present value of the future dividends assuming perfect foresight. ${ }^{5}$ Figure 2 below is the result of such a methodology. The implicit rate series starts in 1441, the first year for which we have both a stock price and a dividend. We observe that the implicit discount rate is quite volatile. This is taken into account in our reduced-form asset pricing model in which the discount rate can vary over time. Moreover, the episode of negative discount rates at the end of the sample period suggests that the poorly-compensated nationalization was not fully reflected into stock prices.

\section{[Insert Figure 2 here]}

In what follows, we explore further the relationship between stock prices and expected future dividends by proposing and testing a reduced-form asset pricing model. In the model, we relax the hypothesis that equilibrium prices are perfect forecasts of future dividends and instead assume that agents use past observations of the dividends to build their expectations. We also relax the hypothesis of a fixed discount rate and instead consider a variable risk correction.

In particular, we specify a model with persistent dividends and a time-varying risk correction. The dividend is assumed to follow an ARMA $(1,1)$ process. ${ }^{6}$ The discount rate is stochastic and assumed equal to the risk-free rate plus a shock. We follow Lettau and Wachter (2007) and assume that only dividend risk is priced: the risk discount that corrects the price of the Bazacle shares for systematic risk is only driven by the covariance between the shock to the discount rate and the shock to dividends. ${ }^{7}$ This risk correction is assumed

\footnotetext{
${ }^{5}$ We thank the referee for this insight

${ }^{6}$ The Akaike Information Criterion suggests that such ARMA model displays the best fit for our dividend data.

${ }^{7}$ Since, as shown below, Bazacle's dividends and prices are stationary, our model and empirical analyses focus directly on prices and dividends. The risk correction thus corresponds to a discount in the price of shares: riskier assets require lower prices for investors to be willing to hold them. If we instead had to rely upon returns and dividend growth, the risk correction would materialize as a premium, i.e., an additional rate of return that compensates investors for holding risky assets.
} 
to be autoregressive of order one. ${ }^{8}$ Given these assumptions, we explicitly derive the equilibrium pricing formula. We show that the stock price can be represented as a linear function of dividends, dividend shocks, and the risk correction. We then estimate the model on the Bazacle company's dividends and prices expressed in real terms, i.e., in kilos of silver. ${ }^{9}$

We proceed in the following manner. We first fit an $\operatorname{ARMA}(1,1)$ model to the dividend process. We extract the ARMA parameters as well as the shocks to dividends. We then run a GLS regression of the share price on the dividends and the dividend shocks. ${ }^{10}$ This enables us to estimate the parameters of the pricing function. The autocorrelation of the regression residuals enables us to identify the evolution of the risk correction.

To test the model, we derive theoretical predictions from the fact that asset prices should vary according to expected future dividends. Since the dividend process is autocorrelated in our model, prices should react to past dividends and dividend shocks because these variables forecast future dividends. In addition, the average level of stock prices should equal the average level of discounted dividends, as estimated independently from the dividend process. We test these predictions by using the delta method to construct confidence intervals.

For these tests, our period of study ranges from 1441, the first year for which we have both dividend and price data, up to 1946. We check the robustness of our results over different subsample periods. The $1532-1815$ period is particularly interesting because we have few missing observations after 1532, and because the business activity and the governance of the firm is known to be stationary over this period.

Our estimates show that the dividend process is persistent with an autoregressive coefficient around 0.80 and a moving-average coefficient around -0.35. These estimates imply that a shock on dividends is reversed by $55 \%$ after one year and by $95 \%$ after eleven years. Estimating the pricing equation, we find that prices are positively related to dividends and

\footnotetext{
${ }^{8}$ Our analysis of the estimated risk correction suggests that it is indeed autoregressive of order one. This indicates that our model does not appear misspecified.

${ }^{9}$ The results are identical if, instead of silver, we use the primary consumption asset wheat as numéraire.

${ }^{10}$ Pagan (1984) shows that such a two-step methodology produces efficient estimators.
} 
negatively related to shocks to dividends. This is consistent with the asset pricing model's predictions given the respectively positive and negative autoregressive and moving-average coefficients estimated for the dividend process. This indicates that the basic pricing equation has good qualitative properties. Moreover, we find that between $15 \%$ to $43 \%$ of the variation in share prices is related to the variation in dividends and dividend shocks. Finally, quantitative tests of our theoretical predictions show that they are not rejected at conventional levels of confidence.

These findings speak to the literature on the predictability of stock returns and dividend growth. ${ }^{11}$ Our findings about the existence of a link between share prices and expected future dividends are consistent with recent results documented by Chen (2009) using US data on dividends starting from 1872 up to World War II, by van Binsbergen and Koijen (2010) on US data from 1946 to 2007 using a Kalman filter approach applied to dividends, and by Chen, Da, and Priestley (2012) from 1871 to 2006 using net payout and earnings (which are more difficult to smooth than dividends).

For example, van Binsbergen and Koijen (2010) indicate that from $13 \%$ to $31 \%$ of the variation in the price-dividend ratio is explained by the variation in expected dividend growth. Our result that cash-flow news explains a significant portion of Bazacle share price variation is also consistent with Vuolteenaho's (2002) finding that firm-level stock returns are mainly driven by cash-flow news and with Jung and Shiller's (2005) finding that individual dividend-price ratios are negatively related with future dividend growth for U.S. stocks over the period after 1926.

Our work is also related to studies that address the limitation of time-series stock market data by extending data collection back in time. Longer time-series, for example allow clean tests of long-horizon predictability - see for example, Goetzmann, Ibbotson and Peng (2001)

\footnotetext{
${ }^{11}$ See for example Fama and French (1988), Campbell and Shiller (1988), Goetzmann and Jorion (1993, 1995), Bossaerts and Hillion (1999), Stambaugh (1999), Goyal and Welch (2003, 2006), Lewellan (2004), Menzly, Santos, and Veronesi, (2004), Ang and Bekaert (2005), Cochrane (2008), and Pástor and Stambaugh (2009).
} 
who use U.S. data from 1818 forward, and Golez and Koudijs (2014) who construct an index spanning four centuries using Dutch, British and U.S. stock returns. These authors focus on Northern European exploration and financial companies from the Netherlands and Great Britain for the early portion of their sample and find that cash flow news dominates discount rate news, with dividend yields predicting future dividend returns. Their findings are consistent with our analysis using a quite different kind of enterprise.

Goetzmann and Jorion (1995) point out that these very long term studies condition on survivorship, which biases towards finding mean reversion in dividend yields. They argue that, since the inverse of the price forecasts future returns, a rebound in price maybe due to survival conditioning. Since the present study focuses on the longest-surviving shareholding company in history this potential bias is important to consider. Before disappearing in the 20th century by being removed from the private sector, the firm experienced several catastrophes, including destructions of physical capital by flood and by fire and two periods of dividend cessation. These events allow us to examine the behavior of prices around events that called into question the resumption of future dividends. Since we specify our model without scaling by prices we do not impose a structure that allows survival to bias results towards finding yield reversion. In addition our specification does not bound dividend price ratios above zero. Finally, we can study whether the stock price is anchored to fundamentals on a time-series basis. ${ }^{12}$

Our theoretical and empirical framework also enables us to estimate the term structure of the risk premium. In particular, we show that, in our model, the term structure of the risk premium is downward-sloping, a result that is in line with the theoretical and empirical analyses of Lettau and Wachter (2007), van Binsbergen, Brandt, and Koijen (2012), and van Binsbergen, Hueskes, Koijen, and Vrugt (2013) on modern data. The one-year risk premium estimate is around $15 \%$ while the fifty-year risk premium appears virtually null.

\footnotetext{
${ }^{12}$ See Campbell and Cochrane (1999) for an examination of the time-series of the aggregate price-dividend ratio in the US over the past century and its comparison with a habit-formation model predictions.
} 
Overall, our results suggest that modern asset pricing theory, yielding the present-value relation, is relevant for the pricing of the Bazacle company's shares from the Middle Ages onward. Whether this was the result of financial models of present value developed in the Western Mediterranean in the Middle Ages, or whether the risk correction and rational expectations about future dividends and prices appeared naturally as an economic response to uncertainty is a question for future research. ${ }^{13}$

The paper is organized as follows. In the next section we provide historical background on the company. Section 3 presents our data sources. In section 4 we adapt basic asset pricing theory to the peculiar circumstances of the Bazacle company, taking into account the fact that dividends, or more precisely net cash flows to shareholders, are stationary and sometimes negative. Section 5 details our econometric methodology. Section 6 presents our results. Section 7 concludes.

\section{Historical background}

Sicard (1953) provides a detailed study of the Honor del Bazacle up to $1472 .{ }^{14}$ Our contribution is the collection of data for the company over the period 1472 to 1946 . For this we rely on corporate documents extant in the Haute-Garonne and Toulouse archives. These contain information on transaction prices, revenues, expenses and dividends. They are also the principal basis for our understanding of corporate operations up through modern times. In this section we provide a brief history of the company and an overview of relevant institutional details useful for understanding share prices and dividends.

\footnotetext{
${ }^{13}$ Fibonacci introduced net present value calculations without a risk premium in his arithmetic training for Italian merchant in the early 13 th century, and risk premiums for maritime voyages were likewise quantified in required rates of return since antiquity, cf. Goetzmann (2006, 2016).

${ }^{14}$ See also Saboly (2001), Goetzmann and Pouget (2011) and le Bris, Goetzmann and Pouget (2014) for more historical information on the Bazacle company.
} 


\subsection{Brief history}

The Bazacle company was - and still is - located on the right bank of the Garonne river near a natural ford used since antiquity. Figure 3 shows the exact location of the mills in the Toulouse city area. A mill in this location was first mentioned in 1071 and, by 1248, twelve mills operated at the Bazacle. These mill companies merged in 1372 to form the Honor del Bazacle. Shares in the company were called uchaux and shareholders were called pariers. Its principal source of revenue was a fee of $1 / 16$ of the grain brought to the mill, which was distributed periodically through the year to shareholders (these distributions were called partisons). ${ }^{15}$

[Insert Figure 3 here]

The firm also leased secondary, unoccupied milling spaces and fishing rights to the Bazacle section of the river and these secondary revenues covered a portion of operating expenses. The remaining operational deficits were charged during the year to shareholders who paid their contribution (called talha) in specie.

The Honor del Bazacle converted its operations to hydroelectricity generation in 1888 and became a Société Anonyme called Société Toulousaine du Bazacle in 1910. Its shares traded on both the Toulouse and Paris stock exchanges in the early 20th century. It was nationalized in 1946 along with all French electricity producers to form EDF, the national public electricity utility.

\footnotetext{
${ }^{15}$ The fee charged by mills in the Toulouse region was fixed by the municipal authorities in the 12 th century. Clients were free to direct their wheat to any mill but all mills were required to charge the same regulated fee. Competition to attract clients could thus only affect quality but not pricing of milling services. Mills could also try and increase their profitability by increasing their productivity.
} 


\subsection{The Honor del Bazacle's institutional relation to the modern corporation}

In a separate paper, Le Bris, Goetzmann and Pouget (2015), we discuss the institutional characteristics of the Honor del Bazacle in detail and analyze its evolution to a modern shareholding corporation as a solution to fundamental economic problems. Sicard (1953) makes a strong case that the Honor del Bazacle was essentially a corporation as we now define it. Its shares were fully transferable. Records of the sale of shares show that approval of the firm was not required for the ownership transfer. It had a juridical personality. Legal proceedings from as early as the 14th century treat the Honor del Bazacle as a legal entity apart from its shareholders. It had limited liability. When shareholders could not pay their contributions, their shares reverted to the company. Shares entitled owners to a distribution of dividends on a prorata basis.

The firm was a private, profit-seeking enterprise. The investors in the Honor del Bazacle did not have a direct role in the firm's management, except through the duties related to participation in the board of directors. The governance of the firm resembled that of modern corporations. The company operations were controlled by a rotating board of directors appointed by a shareholder vote at an annual meeting, a time at which financial accounts were produced and the contribution determined. By the mid 16th century, the governance and management structure of the Honor del Bazacle included a chief operating officer, a treasurer and a clerk. This basic structure continued into the 19th century and up to modern times. 


\section{Data}

\subsection{Share prices}

\subsubsection{Sources}

The founding charter, with agreed valuation of the contributed shares of the underlying twelve firms that constituted the company, is still extant in the archives of Toulouse. This charter gives us the first stock price of our series. From that point onward, transactions of shares in the Bazacle company were recorded by notaries, along with the price in livres tournois, which was the currency of account in France. ${ }^{16}$ Fractional transactions of shares were allowed, so the number of shares did not necessarily limit the number of shareholders.

Our data collection effort takes up where earlier data collection left off (i.e., in 1450). However, rather than relying on notarial records of public sales, we use company shareholder registers. The Honor del Bazacle maintained meticulous documentation about distributions to shareholders, but only a few registers from the 15th century were preserved. From the early 16th century onward, the series of registers offers a nearly complete record of share ownership and transfer. Each page of the shareholder account book (i.e., register of distributions) corresponds to one shareholder and indicates the grain received during a given year. When share transactions occurred, a notation in the margin recorded the date, the price and the name of the new shareholder. This enabled the company to distribute the grain dividend to the appropriate owner.

For the period after 1532 , we are able to collect transaction data from a new register (the register of shareholders, created by the company to follow the owners of shares) that reports not only transactions but also the number of shares in each shareholder's account. Each page of the register of shareholders corresponds to one shareholder with the name and the

\footnotetext{
${ }^{16}$ Livres tournois or Tours pounds were the basis of the French monetary system for a very long time period, from the Middle Ages up to 1803. The Louisiana Purchase concluded between Jefferson and Napoleon in 1803 was, for example, still denominated in livres tournois.
} 
number of shares he or she owned. Potential successive sales of shares are written below his or her name. Fractional ownership of shares was common, with, for example, one transaction record for $1 / 60$ th of half a share (i.e., 1/120th of a share). For example, Figure 4 shows the register of shareholders from 1532 for Jean de Bernuy, a rich pastel merchant from Toulouse.

[Insert Figure 4 here]

A last source of prices comes from a tax (of 1\%) on notary-recorded transactions (called "centième denier") created in 1703. The bureau of Toulouse recorded in an annual register the tax collected indicating the date, contracting parties, nature, object and price of the transaction. This tax still exists and has been called "Droits d'enregistrement" since the Revolution. ${ }^{17}$ Most of these registers are available in the archives of the Haute-Garonne. For years without price from others sources, i.e., between 1703 and 1887, we went through the entire registers to find transactions.

After 1887, the local newspaper, "La Dépêche du Midi", provides data from the "Bourse de Toulouse" where the shares traded, and we collect price data from this source, although it lacks volume information. In addition, national newspapers and the "Cote Officielle de la Bourse de Paris" reported share prices, since the firm was listed on the Paris stock exchange in 1910. For this last period, we collected the last price of the year that could be identified.

\subsubsection{Shares outstanding}

Despite its very long life, the capital structure of the firm is straightforward to reconstruct. The Appendix reports the history of the firm's outstanding capital in Subsection 8.1. The company started in 1372 with 80 shares. As of 1384, 16 new shares had been created and exchanged for two mills that remained independent after the initial merger - an early example

\footnotetext{
${ }^{17}$ See Hoffman, Postel-Vinay, and Rosenthal (2000) for a study of French Ancien Regime markets.
} 
of a corporate acquisition. The number of shares rose from 96 to 100 in 1535 for reasons unclear - perhaps to simply make the accounting easier. When some shares occasionally reverted to the firm due to shareholder surrender, these were immediately auctioned, keeping the shares outstanding constant. Most of the time, when the firm needed new money, a high contribution was imposed, instead of new shares issued.

In 1714, a major capital infusion was necessary in order to repair the milldam and the

number of shares increased to 128. At this time, an engineer, M. Abeille, took over half of the equity of the firm thanks to investment capital from Genevan financiers. The mills resumed operations in 1720 after 12 years of inactivity.

On May 29th, 1803, 8 new shares were created and sold to finance repairs. In 1888, following a devastating fire and a strategic reassessment, each share was divided into 4 shares. In 1910, the firm merged with the "Société Toulousaine d'Electricité" to create the "Société Toulousaine du Bazacle": each shareholder from the Bazacle received, per share, 70 francs and 6 shares of the new company. Between 1927 and 1928, the capital of the firm was reorganized (in the form of a merger between different kinds of stocks followed by a split). From that time until the nationalization in 1946, the capital was only affected by a stock issuance in 1943.

\subsection{Dividends}

As discussed above, calculating dividends requires information about the distribution of grain to shareholders, the value of this grain and the annual assessment of the contribution. We discuss each of these in turn.

\subsubsection{Distribution of grain}

The distribution of grain occurred around 13 times per year on average until 1817, at which point dividends were paid in specie. We collected data from the registers for about 4,000 
distributions, beginning in $1439 .{ }^{18}$ These registers indicate the quantity of wheat paid to each shareholder during the year.

There are two series of yearly registers of distributions: one series records the distribution per day of distribution and a second series records the distribution per shareholder for purposes of control. For a given year, if one shareholder did not receive the correct amount, the register mentioned the quantity that should be reported in the next year to compensate for the missing quantity.

\subsubsection{Grain value}

Shareholders received wheat to their account as a result of distributions, and then could readily monetize it through sale, although they could also retain grain for their own use. Indeed, registers of distributions always mention the price of wheat on the day of the distribution after 1584 and otherwise only on the occasion of a sale of wheat by the firm on behalf of the shareholder to pay the contribution.

Before 1584, we obtain data on the monthly price of wheat in Toulouse from Frêche and Frêche (1967) that allows us to convert the dividends into a single unit of account (livres tournois then converted into kilograms of silver) for purposes of analysis.

\subsubsection{Shareholder contribution}

Data on shareholder contributions to expenses come from three sources: distribution registers, registers of the general meetings during which shareholders voted the amount of the contribution, and the accounting registers which recorded the monetary transactions of the firm. Contributions became less frequent through the 18th century. Instead, some wheat was sold for cash for the benefit of the firm.

\footnotetext{
${ }^{18}$ The first year with a documented dividend is 1439 and the first year with both a dividend and a share price documented is 1441 .
} 
The contributions were denominated in livres tournois except during the French Revolution. After February 1796, due to the extreme inflation of paper money during the revolution, the amount of the contribution was set as a percentage of the distribution. After this date, and despite the return of a strong currency with the "franc germinal" in 1803, the principle of the contribution was never reintroduced, except for one last, huge one in 1814 to repair the mills. A standard dividend appeared after 1843, which corresponds to the year of the Bazacle's first modern accounting, ending a system that began in the 14th century.

\subsubsection{Net Dividend}

For the period before 1816, we calculate the yearly net dividend as the value of the distributions during the year minus the amount of the contribution for that year. ${ }^{19}$ From 1816 to 1843 , the dividend was a payment made by the firm to shareholders after operating costs were deducted from revenues. After 1843, the firm distributed a standard dividend. We collect these data from the accounting registers and, after 1887, from various newspapers.

The dividend record is somewhat more complete than the share price transaction record. Only 30 dividend records exist for the entire period 1372-1531, but there is only 1 missing year between 1532 and 1813. There are 33 years of missing dividend information between 1814 and 1887 due to a missing register, and none after this date.

Dividends could of course be negative because we calculate them as the difference between the distributions valued at prevailing wheat prices and the shareholder contributions for that year. As explained above, large negative dividends generally corresponded to years in which floods destroyed the mills or the milldam and thus can also be thought of as occasional capital investment in repair.

\footnotetext{
${ }^{19}$ It would be possible to consider each call for capital as an issue of new shares that shareholders do subscribe. We thank the referee for pointing this out. This would require computing an artificial theoretical number of shares and theoretical dividend per share. The result would be an artificial increase in the number of outstanding shares and decrease in the dividend per share. We have preserved the Bazacle accounting method for purpose of simplicity. We believe this method does not change the results of our analysis.
} 
From an econometric perspective, an important advantage of the annual complete disbursements of profits is that the firm did not smooth dividends, nor did it self-finance from year-to-year using internal cash flows. Figure 5 shows the annual net dividends, expressed in grams of silver in order to adjust for inflation. ${ }^{20}$ There are a dozen years in which dividends were negative; in four of these, shareholders were required to make net payments equivalent to three to five kilograms of silver per share. ${ }^{21}$ This allows us to estimate an asset pricing model in the absence of managerial dividend smoothing which has long been recognized as an econometrically complicating factor in predictive regressions.

\subsection{Prices and dividends over six centuries}

The time series of prices for Honor del Bazacle shares provides a record of equity investment value from the late Middle Ages to the middle of the 20th century. ${ }^{22}$ Figure 5 plots the latest available price and the net dividend of each year, in silver. We have a total of 417 years with a dividend record and 364 years with a price record. The gap in the price series from 1450 to 1532 is the period between the end of the notarial records studied by Sicard (1953) and Wolff (1954) and the beginning of complete corporate registers. After 1532, the price and dividend series are nearly continuous. In real terms, share prices remained relatively stable through time.

[Insert Figure 5 here]

Prices and dividends tend to move together. This is suggestive evidence that share prices reflect information included in dividends. Below, we set up a model with predictable

\footnotetext{
${ }^{20}$ The Appendix gives, in Subsection 8.2, more information on the expression of dividends and prices in kilograms of silver.

${ }^{21}$ In future work, it would be interesting to study the impact of jumps on asset prices in spirit of Bollerslev, Law and Tauchen (2008) and Tauchen and Zhou (2011).

${ }^{22}$ Among the rare studies of early stock trading, see for example Gehrig and Fohlin (2006), Carlos, Fletcher, and Neal (2012), Koudijs (2016).
} 
dividends that formally captures this idea. ${ }^{23}$

Figure 6 shows the number of transactions per year. By any measure, the turnover is quite low compared to frequently traded modern stocks. However it appears in line with the turnover of infrequently traded stocks in modern markets as discussed by Easley, Kiefer, O'Hara, and Paperman (1996). ${ }^{24}$ Prior to 1888, the average number of transactions per year was less than four, and for the period prior to 1532 , the average was less than $1 .^{25}$ The volume of transactions varies considerably through time, however. For example, the 16th century was a period of relatively high volume, as was the period around the French Revolution. $^{26}$

[Insert Figure 6 here]

\footnotetext{
${ }^{23}$ Most of the low prices for Bazacle shares were associated with the destruction of the mills or of their dam system. Share prices were low after a flood damaged the Bazacle dam in 1638, and 25 shareholders failed to pay their contributions. In 1709, ice flows on the Garonne completely destroyed the Bazacle dam. Whereas the price of one share typically exceeded the price of 20 metric tons of wheat, it fell to the price of 0.76 metric tons of wheat or 878 grams of silver in October, 1709. This crisis caused a high contribution, a number of forfeited shares, and eventually led to a recapitalization of the firm.

The dam was again destroyed in 1736 and share prices dropped in that year to 7.24 metric tons of wheat or $3.2 \mathrm{~kg}$ of silver. A fire destroyed the mills in 1814 imposing a very high (and the last) contribution of $4.5 \mathrm{~kg}$ of silver (1,000 francs) leading to another low price of 5.48 metric tons or $8.1 \mathrm{~kg}$ of silver in 1816 . Another fire in 1887 resulted in a quasi-bankruptcy and financial restructuring that led to the conversion to electricity generation in the late 1880's. The financial conditions of the nationalization in 1946 explain the last two low figures. In sum, most of the periods of low share prices were associated with natural disasters that destroyed the mills or the milldam.

${ }^{24}$ Easley, Kiefer, O'Hara, and Paperman (1996) indicate that "On the New York Stock Exchange (NYSE), it is common for individual stocks not to trade for days or even weeks."

${ }^{25}$ The low turnover was certainly due, in part, to an unusual transaction tax on new shareholders. A new shareholder was required to host a dinner for the board of directors and to display at that time the notary act of his purchase. The dinner was likely expensive because the requirement was eventually changed to a fee of 60 livres in 1731 - about $1 \%$ of the value of a share at that time. As a comparison, the cost of the notary (for the act and the tax) was $4.4 \%$ in the 19 th century.

${ }^{26}$ In addition there were a few instances of massive sales. $16.25 \%$ of the capital turned over in $1597,20.50 \%$ in $1639,50 \%$ in 1714, and $28.50 \%$ in 1738 due to auctions of shares after non-payment of a high contribution. $21.30 \%$ turned over in 1791 due to expropriation and resale of clerical and "émigrés" holdings.
} 


\subsection{Descriptive statistics}

Table 1 reports summary statistics about the annual returns on Bazacle shares. Statistics are computed using the price closest to the end of each calendar year. We use data in grams of silver to neutralize the effect of monetary inflation. Prices and dividends are missing for various years. For capital appreciation returns, we only use years for which prior and current year prices exist. For income returns, we require the dividend from the current year and a price from the previous year. We present statistics for the full sample as well as for various sub-periods, the Middle-Ages from 1372 up to 1531 (for which we do not have a lot of data), the milling activity period from 1532 to 1887 (for which we have plenty of data), and the electricity period from 1888 up to 1946.

\section{[Insert Table 1 here]}

We are able to calculate the dividend yield for 327 years in the full sample. The average dividend yield over this entire period from 1372 to 1946 is around 5\%. ${ }^{27}$ This holds for all the time periods we consider, suggesting stability in income return over centuries. The standard deviation is around $7 \%$ over the full sample period indicating that important fluctuations in the dividend yield were not unusual.

Figure 7 shows the time series of the dividend yield per share. The interruption around the dam destruction and repair in the early 18th century and the period before conversion to electricity production at the end of the 19th century are the only two major periods over which dividend yields were zero. Most of the other gaps are due to missing data. The series is also clearly stationary over the long run. Prices seem to adjust to different levels of (expected) dividends. We give a closer look at this issue in the next sections. For example,

\footnotetext{
${ }^{27}$ Since some of our missing values could correspond to null dividends, the dividend yield might be overestimated, in particular before 1532, a period during which there are more missing values. However, we believe that the overestimation, if any, is limited because the very bad periods without milling activity are known thanks to historical archival evidence and we assume that for these years the dividend is null.
} 
real dividends exceeded 1,000 grams of silver in the 16th century and were considerably less than that in the 18th century, however yields in the two periods were not dramatically different.

\author{
[Insert Figure 7 here]
}

Over the periods from 1532-1888 and from 1889-1946, the arithmetic average annual real capital gains were $18 \%$ and $6 \%$, respectively. The geometric means of the capital gain (not reported here) were slightly negative from 1372 to 1946 and this is also the case for all the sub-periods we consider. Such a near-zero long term capital gain is consistent with the dividend policy of the firm for much of its history - to pay out all earnings. ${ }^{28} \mathrm{~A}$ real price appreciation close to zero is consistent with the fact that prices appear to be stationary. This is reflected in the average price change being close to zero (see the last column of Table 1). ${ }^{29}$ The difference between the low compound growth rate and the high arithmetic mean of the capital appreciation series is consistent with a a log-normal distribution with high volatility.

The volatility of annual capital appreciation series, ranged between $58 \%$ and $134 \%$ per annum after 1532. Such high levels of price uncertainty at the individual stock level would not be particularly unusual in the context of modern equity volatility. The highest volatility was experienced in the period 1532-1888 which also witnessed several major disasters.

\title{
4. Asset pricing model
}

This section adapts the standard asset pricing model to the specificities of the Bazacle company. Phillips-Perron unit root tests reported below enable us to reject non-stationarity

\footnotetext{
${ }^{28}$ This was also the norm for stocks in other markets during the 19th century; see Goetzmann, Ibbotson and Peng (2001).

${ }^{29}$ The average annual capital gain being positive is not in contradiction with the average price change being null. To see this, denote by $P_{t}$ the price of a share at date $t$. The average capital gain is $\mathbb{E}\left(\frac{P_{t+1}-P_{t}}{P_{t}}\right)$. If the average price change $\mathbb{E}\left(P_{t+1}-P_{t}\right)$ is null, we thus have $\mathbb{E}\left(\frac{P_{t+1}-P_{t}}{P_{t}}\right)=\mathbb{C o v}\left(P_{t+1}-P_{t}, \frac{1}{P_{t}}\right)$, which can be positive.
} 
of the dividend and price processes. Moreover, dividends can be negative. We will thus seek to derive equilibrium share prices rather than rates of return.

We start by stating the basic pricing formula as follows:

$$
P_{t}=\mathbb{E}_{t}\left[M_{t+1}\left(D_{t+1}+P_{t+1}\right)\right]
$$

$M_{t+1}$ is the stochastic discount factor at date $t+1$. It is a random variable that represents bad times coming at date $t+1 . D_{t+1}$ is the dividend distributed at date $t+1 . P_{t+1}$ is the post-dividend share price at date $t+1$.

We now give more structure to this equation. To capture the stationarity of the dividend process, we assume that dividends follow an $\operatorname{ARMA}(1,1)$ process:

$$
D_{t+1}=\alpha+\beta D_{t}+\gamma \epsilon_{t}^{D}+\epsilon_{t+1}^{D}
$$

with $\mathbb{E}_{t}\left(\epsilon_{t+1}^{D}\right)=0$.

We model the time varying stochastic discount factor as:

$$
M_{t+1}=\frac{1}{1+r}\left(1+\epsilon_{t+1}^{M}\right)
$$

with $\mathbb{E}_{t}\left(\epsilon_{t+1}^{M}\right)=0$. The variable $r$ represents the risk-free rate of return.

Define the risk correction as $\pi_{t}=-\operatorname{Cov}_{t}\left(\epsilon_{t+1}^{M}, \epsilon_{t+1}^{D}\right)$. We assume that:

$$
\hat{\pi}_{t}=\pi_{t}-\mathbb{E}\left(\pi_{t}\right)=\delta \hat{\pi}_{t-1}+\epsilon_{t}^{\pi}
$$

with $\mathbb{E}_{t-1}\left(\epsilon_{t}^{\pi}\right)=\operatorname{Cov}_{t}\left(\epsilon_{t+1}^{M}, \epsilon_{t+1}^{\pi}\right)=0$.

We now have enough structure to solve explicitly for the share price. To do so, we start with the pricing conjecture:

$$
P_{t}=a+b D_{t}+c \epsilon_{t}^{D}-d \hat{\pi}_{t}
$$


According to this conjecture, the share price depends on two things: the current dividend and the dividend shock because these variables allow prediction of future dividends and a correction that compensates investors for risk.

We plug the above pricing conjecture taken at date $t+1$ into Equation (4.1) to obtain:

$$
P_{t}=\mathbb{E}_{t}\left[M_{t+1}\left(a+(b+1) D_{t+1}+c \epsilon_{t+1}^{D}-d \hat{\pi}_{t+1}\right)\right] .
$$

We rewrite this expression as a function of date- $t$ variables by using Equations (4.2) and (4.3). Rearranging yields:

$$
P_{t}=\frac{a+(b+1) \alpha-(b+c+1) \mathbb{E}\left(\pi_{t}\right)}{1+r}+\frac{(b+1) \beta}{1+r} D_{t}+\frac{(b+1) \gamma}{1+r} \epsilon_{t}^{D}-\frac{(b+c+d \delta+1)}{1+r} \hat{\pi}_{t} .
$$

This equation indicates that the pricing conjecture given by Equation (4.5) is satisfied. Moreover, after identification of Equations (4.6) and (4.5) term by term, we solve for the underlying parameters values:

$$
\begin{aligned}
& a=\frac{1+r}{1+r-\beta} \frac{\alpha}{r}-\frac{1+r+\gamma}{1+r-\beta} \frac{\mathbb{E}\left(\pi_{t}\right)}{r}, \\
& b=\frac{\beta}{1+r-\beta}, \\
& c=\frac{\gamma}{1+r-\beta}, \\
& d=\frac{1+r+\gamma}{(1+r-\beta)(1+r-\delta)}
\end{aligned}
$$

These parameters indicate how share prices respond to the expected level of dividends and of risk correction (parameter $a$ ), to the current dividend and dividend shock (parameters $b$ and $c$ ), and to the current level of risk correction required by investors (parameter $d$ ).

The economic interpretation of the pricing formula is as follows. If the conditional expectation of dividends is a constant, i.e., if $\beta=\gamma=0$, then the parameter $a$ equals $\frac{\alpha}{r}$ and 
the price does not respond to changes in dividends. This is reminiscent of the classic case in which the dividend is an invariant perpetuity and is discounted at a fixed rate $r$. If there is time dependence in the dividend process, i.e., if $\beta \neq 0$ or $\gamma \neq 0$, then the price reflects such dependency and reacts to changes in dividends. The share price also depends on the risk correction. If the risk correction is very persistent, $\delta$ is close to one and the price reacts a lot to risk correction changes.

\section{Econometric methodology}

This section discusses how we identify and estimate the deep parameters of our asset pricing model. It also indicates how we can test the model by deriving various theoretical predictions.

\subsection{Identification and estimation method}

It is straightforward to see that parameters $\alpha, \beta$, and $\gamma$ are directly identified using the estimation of Equation (4.2) on dividend data. This estimation also yields an estimate of the process $\left\{\epsilon_{t}^{D}\right\}$. We estimate the $\operatorname{ARMA}(1,1)$ process given by Equation (4.2) by maximum likelihood.

Estimating Equation (4.5), using price and dividend data and the estimates of the dividend shocks, enables us to identify parameters $a, b$, and $c$. Note that, as indicated in Section 3 of Pagan (1984), a two-step regression produces efficient estimators. It is thus appropriate to first estimate Equation (4.2) and then to use the dividend and dividend shocks in the second-step regression to estimate the pricing equation, Equation (4.5).

Since both $d$ and the variance of $\epsilon_{t}^{\pi}$ are associated multiplicatively, we cannot directly identify them separately. However, we can identify $\delta$, the autoregressive coefficient of the process $\hat{\pi}_{t}$, as the autocorrelation between the residuals of the regression of $P_{t}$ on $D_{t}$ and $\epsilon_{t}^{D}$. The GLS regression given by Equation (4.5) is estimated by maximum likelihood. The 
parameter $d$ is identified thanks to Equation (4.10). We can then identify the variance of $\epsilon_{t}^{\pi}$.

The last parameter that we can identify is the average risk correction, $\mathbb{E}\left(\pi_{t}\right)$. We do so by plugging in Equation (4.7) the parameter $r$ extracted from Equations (4.8) or (4.9) as well as the parameters estimated thanks to Equation (4.2). We obtain the following formula:

$$
\mathbb{E}\left(\pi_{t}\right)=\frac{(1+r) \alpha-\operatorname{ar}(1+r-\beta)}{1+r+\gamma}
$$

To evaluate the statistical significance of our parameters' estimations, p-values are based on standard errors computed with the delta method.

\subsection{Theoretical predictions}

Our theoretical predictions derive from the fact that prices reflect expected dividends. This basic economic insight imposes precise restrictions on how prices should respond to past dividends and dividend shocks. Also, this insight implies that, unconditionally, average prices should accurately reflect the average level of dividends.

A first prediction of our model is that, when $1+r-\beta>0$, parameters $b$ and $c$ should display the same sign as parameters $\beta$ and $\gamma$, respectively. This comes from the fact that prices reflect expected future dividends and thus should appropriately incorporate the autoregressive and the moving average nature of the dividend process.

A related theoretical prediction derives from the model making precise, through Equations (4.8) and (4.9), how much prices should respond to dividends and dividend shocks, respectively. Combining these two equations, we observe that the price reaction to dividends relative to dividend shocks, measured by the ratio $\frac{b}{c}$, should be proportional to the autoregressive and moving-average coefficients, $\beta$ and $\gamma$, respectively. To see this, combine Equations (4.8) and (4.9) to get:

$$
\frac{b}{c}-\frac{\beta}{\gamma}=0
$$


Provided that the dividend and process is stationary, the unconditional expectation of dividends, $\mathbb{E}\left(D_{t}\right)$, is given by Equation (4.2) as $\frac{\alpha}{1-\beta}$. Provided that the price process is stationary, plugging this expression into the pricing formula, Equation (4.5), yields a last theoretical prediction:

$$
\mathbb{E}\left(P_{t}\right)-\left(a+b \frac{\alpha}{1-\beta}\right)=0
$$

We test the last two theoretical predictions by using the delta method to build standard errors and confidence intervals. This enables us to test whether the asset pricing model is rejected by the data. ${ }^{30}$

\section{Empirical results}

We first focus on the estimation of the dividend process and then proceed to study the pricing of the Bazacle shares.

We use several sample periods to gauge the robustness of the results. Our analysis starts in 1441 which is the first year for which we could collect both a price and a dividend observation. The full sample period is interesting because it is the longest time series that we could gather, from 1441 to 1946. Another interesting sample period ranges from 1532 to 1815 because it is a time in which there was no change in the business activity or the governance of the Bazacle company. Missing values are linearly interpolated. Using linear interpolation is not a major concern since, after 1532, we have few missing data (over 415 years, from 1532 to 1946, 28 dividends and 83 stock prices are missing) and the results are robust across time periods. Moreover, our results hold if we simply omit missing values.

\footnotetext{
${ }^{30}$ Note that our quantitative tests of asset pricing theory are meaningful because they involve relationships between coefficients obtained from two separate estimations.
} 


\subsection{Stationarity}

Table 2 reports the results of Phillips-Perron unit root tests. The null hypothesis is that the series is not stationary: a small p-value thus indicates that we can reject non-stationarity. The tests are run for both dividends and stock prices, and for the various time periods under consideration.

[Insert Table 2 here]

Table 2 indicates that both the dividend and stock price processes appear stationary. This is in line with the stable business model, governance and economic environment of the Bazacle company over the long run. However, dividends and stock prices appear quite volatile which indicates that they are affected by numerous shocks.

\subsection{Dividend process}

We fit the $\operatorname{ARMA}(1,1)$ model represented in Equation (4.2) to the dividend series that we collected. ${ }^{31}$ The estimation results are presented in Table 3.

[Insert Table 3 here]

The estimation indicates that the dividend process is persistent. The parameter $\beta$ is indeed positive and close to 1 in all the sample periods considered. Dividend shocks appear to revert: the parameter $\gamma$ is indeed negative. But this reversal does not cancel the persistence: overall, the sum of the parameters is significantly positive. This indicates that there

\footnotetext{
${ }^{31}$ Unreported tests based on the Akaike Information Criterion suggest that an ARMA $(1,1)$ model provides the best description of our dividend data, in the class of ARMA models. This echoes the findings of Yang, Koo and Wilson (1992), who find that an ARMA(1,1) model is a good fit for wheat yields (the main grain milled by the Bazacle company), and of Bessler (1980), who tests subjective farmer beliefs about the intertemporal crop yield variation with an ARIMA model and finds reasonable beliefs about time-series model parameters.
} 
is predictability in the dividend process. The next subsection tests whether share prices accurately reflect this predictability.

\subsection{Share prices}

We use share prices, dividends and the dividend shocks extracted above to estimate the pricing Equation (4.5). The GLS regression that it describes is estimated via maximum likelihood. The results are in Table 4.

[Insert Table 4 here]

The coefficients $b$ and $c$ are significant, indicating that share prices incorporate some information from dividends and dividend shocks. Moreover, the signs of the coefficients, positive for $b$ and negative for $c$, are in line with the asset pricing model's predictions: Equations (4.8) and (4.9) predict that, provided that the denominator is positive, the signs of $b$ and $c$ should be the same as the signs of $\beta$ and $\gamma$, respectively. This is exactly what we find in the data. This provides us with a first indication that asset pricing theory is useful to qualitatively understand our data.

Based on the estimates presented in Table 4, we can estimate what proportion of share price variations are due to changes in expectations of future dividends. This is in spirit of the seminal analyses of Shiller (1981) and Leroy and Porter (1981). Taking the variance of the price as given in Equation (4.5) indicates that the proportion of price volatility associated

with variation in dividends and dividend shocks is: $\frac{b^{2} \operatorname{Var}\left(D_{t}\right)+c^{2} \operatorname{Var}\left(\epsilon_{t}^{D}\right)}{\operatorname{Var}\left(P_{t}\right)}$. This proportion is indicated in Table 4 under the title pseudo- $R^{2}$.

The proportion of price variations explained by changes in expectations of future dividends ranges from $15 \%$ to $43 \%$. This result is in line with recent conclusions from the empirical asset pricing literature. Chen (2009) uses data on the aggregate US stock market 
and shows that dividend-price ratio changes predict future dividends over the period ranging from 1872 to World War II. Such predictability disappears in the second part of the twentieth century, possibly because of the tendency to smooth dividends.

Moreover, Chen, Da, and Priestley (2012) use data from 1871 to 2006 and show that, using net payout and earnings (that are more difficult to smooth) instead of dividends, predictability does not disappear after WWII. It is remarkable that, during the period before 1815 during which dividends of the Bazacle company corresponded exactly to earnings, we find the closest relationship between share prices and expectations of future dividends. ${ }^{32}$

Also, using a Kalman filter approach on data from 1946 to 2007, van Binsbergen and Koijen (2010) are able to identify some predictability of future dividends thanks to the dividend-price ratio: they find that between $13 \%$ and $31 \%$ of the variation in the pricedividend ratio is explained by variations in expected dividend growth. These figures are very similar to what we find for the Bazacle company over several centuries. Finally, our result that dividend forecasts explain a significant portion of Bazacle share price variations is consistent with Vuolteenaho (2002)'s finding that, in the US market from 1954 to 1996, firm-level stock returns are mainly driven by cash-flow news.

We also estimate the autoregressive coefficient of the risk correction, $\delta$. Table 4 shows this to be high - between 0.76 and 0.81 depending on the sample period. This suggests that the risk correction is persistent. The persistence in the risk correction appears higher than that of the dividend. This result is also consistent with the findings of van Binsbergen and Koijen (2010) who show that expected returns are more persistent than expected dividend growth rates.

\footnotetext{
${ }^{32}$ Koudijs (2016) offers useful insights on stock price volatility using a natural experiment from Amsterdam stock exchange in the 18th century by comparing periods with and without news arrival.
} 


\subsection{Risk premium and its term structure}

Our theoretical framework enables us to compute the equity risk premium, the expected return on a stock in excess of the risk free rate, as: ${ }^{33}$

$$
\begin{aligned}
\mathbb{E}_{t}\left[R_{t+1}^{e}\right] & =-(1+r) \operatorname{Cov}_{t}\left(M_{t+1}, R_{t+1}^{e}\right) \\
& =\frac{(1+b+c) \pi_{t}}{P_{t}}, \\
& =\frac{1+r+\gamma}{1+r-\beta} \frac{\pi_{t}}{P_{t}}
\end{aligned}
$$

where $R_{t+1}^{e}=\left(P_{t+1}+D_{t+1}\right) / P_{t}-(1+r)$.

The equity risk premium in our model is thus time-varying and increases in bad times, when $\pi_{t}$ is large.

Our framework also enables us to study the term structure of the risk premium. This issue is crucial for long term investments and has been the focus of significant research in the financial economics literature (see, for example, Lettau and Wachter (2007), van Binsbergen, Brandt, and Koijen (2012), and van Binsbergen, Hueskes, Koijen, and Vrugt (2013)).

The price of the $n$-period claim, or dividend strip, is denoted by $P_{t}^{n}$, and satisfies: $P_{t}^{n}=$ $E_{t}\left[M_{t: t+n} D_{t+n}\right]$, where $M_{t: t+n}$ denotes the product of the stochastic discount factors, $M_{t: t+n}=$ $\prod_{s=1}^{n} M_{t+s}$. We can compute dividend strip prices recursively as $P_{t}^{n}=E_{t}\left[M_{t+1} P_{t+1}^{n-1}\right]$.

One can show by induction that:

$$
P_{t}^{n}=A_{n}+B_{n} D_{t}+C_{n} \epsilon_{t}^{D}+D_{n} \pi_{t}
$$

with $A_{1}=\alpha /(1+r), B_{1}=\beta /(1+r), C_{1}=\gamma /(1+r)$, and $D_{1}=-1 /(1+r)$, and, for all $n>1$ :

- $A_{n}=\left(A_{n-1}+B_{n-1} \alpha+D_{n-1} E\left[\pi_{t}\right](1-\delta)\right) /(1+r)$,

\footnotetext{
${ }^{33}$ Using the standard equations $\mathbb{E}[M R]=1=\operatorname{Cov}(M, R)+\mathbb{E}[R] \mathbb{E}[M]$, implying $\mathbb{E}[R]=(1-$ $\operatorname{Cov}(M, R))(1+r)$.
} 
- $B_{n}=\beta B_{n-1} /(1+r)$

- $C_{n}=\gamma B_{n-1} /(1+r)$,

- $D_{n}=\left(-B_{n-1}-C_{n-1}+\delta D_{n-1}\right) /(1+r)$.

Note that the solutions for $B_{n}$ and $C_{n}$ are $B_{n}=\beta^{n} /(1+r)^{n}$ and $C_{n}=\gamma \beta^{n-1} /(1+r)^{n}$. Given the parameter estimates we find, we have: $B_{n}>0, C_{n}<0$, and $B_{n}+C_{n}>0$, for all $n$.

The expected excess return on dividend strips can then be computed as: ${ }^{34}$

$$
\begin{aligned}
E_{t}\left[R_{t+1}^{e, n-1}\right] & =-(1+r) \operatorname{Cov}_{t}\left(M_{t+1}, R_{t+1}^{e, n-1}\right) \\
& =-\frac{\operatorname{Cov}_{t}\left(\epsilon_{t+1}^{M},\left[B_{n-1}+C_{n-1}\right] \epsilon_{t+1}^{D}\right)}{P_{t}^{n}} \\
& =\frac{\left(B_{n-1}+C_{n-1}\right) \pi_{t}}{P_{t}^{n}}
\end{aligned}
$$

where $R_{t+1}^{e, n-1}=P_{t+1}^{n-1} / P_{t}^{n}-(1+r)$.

This equation shows that, in bad times, $\pi_{t}$ increases and the risk premium on a given dividend strip rises. Moreover, we can use our parameter estimates to derive the term structure of the risk premium. To do so, we simulate Equation 6.14 and find that the term structure of risk premia is downward-sloping. ${ }^{35}$ This is similar to the theoretical results obtained by Lettau and Wachter (2007).

As an illustration, Figure 8 plots the term structure of the discount rate for the parameters estimated over the entire 1441-1946 period. The one-year risk premium is around 15\% while the fifty-year risk premium is virtually null. This is because, in our model, discount rate shocks are not priced and dividend shocks are reverted. This result that the short-term risk premium is higher than the long-term one is in line with the empirical results of van Binsbergen, Brandt, and Koijen (2012), and van Binsbergen, Hueskes, Koijen, and Vrugt

\footnotetext{
${ }^{34}$ Using the standard equations $E[M R]=1=\operatorname{Cov}(M, R)+E[R] E[M]$, implying that $E[R]=(1-$ $\operatorname{Cov}(M, R))(1+r)$.

${ }^{35}$ To run our simulation, we use our parameter estimates and a grid that includes dividend values $D_{t}$ from 800 to 2,000 , dividend shocks from -900 to +800 , and a risk correction $\pi_{t}$ of 247 or 300 .
} 
(2013). The average level of the risk premium is $10.44 \%$, a level that seems reasonable given the high level of volatility of the Bazacle company's returns and the probably high level of correlation between the return of the Bazacle and aggregate consumption. ${ }^{36}$

[Insert Figure 8 here]

\subsection{Tests of the asset pricing model}

We quantitatively test the asset pricing model by studying the two theoretical predictions displayed in Equations (5.11) and (5.12). We use the delta method to generate standard errors and $95 \%$ confidence intervals for the left-hand side of these equations. The results are in Table 5.

[Insert Table 5 here]

The $95 \%$ confidence intervals for all the sample periods include zero. We thus cannot reject the hypothesis that the equalities in Equations (5.11) and (5.12) are true at a conventional level of significance. Moreover, the model is only rejected with very high p-values (and thus low levels of confidence), higher than $46 \%$.

Our asset pricing model, in addition to making predictions that are qualitatively verified, cannot be quantitatively rejected at usual levels of significance. This result suggests that the principles of asset pricing theory likely governed the price formation process even in the early history of the firm.

In addition, unreported estimates suggest that we cannot reject, at the $95 \%$ confidence level, the fact that the risk-free rate is close to zero. A low risk-free rate makes sense given that we are focusing on real rates and given the low average growth for most of the time period under consideration.

\footnotetext{
${ }^{36} \mathrm{~A}$ complete analysis of the equity premium and of its adequacy is beyond the scope of the present paper.
} 


\section{Conclusion}

The Bazacle company existed over several centuries and for much of that time it generated a variable flow of dividends punctuated by occasional disasters. Shares in this early example of corporate enterprise were traded at market prices. Our analysis examines whether expected future dividends are accurately reflected in share prices and the nature of the risk that was priced by investors.

A simple finding of our study is that real income returns, constituted by the dividend yield, were slightly in excess of $5 \%$ over most of the firm's life. The key test in the paper is whether or not an asset pricing model, estimated directly on prices and dividends - not on yields and returns - is rejected by the data. We find it is not. Further, changes in expectations of future dividends explain a significant fraction of price variations - a finding consistent with the relative importance of cash flow vs. discount rate news for individual firms. Our data allow us to estimate a term structure for the equity premium: we find a downwind-sloping term structure of equity risk premia.

Since calculations and inferences are drawn for the Bazacle company, there is no crosssectional evidence involved and usability is thus restricted. Moreover, there is a potential concern about survivorship bias that cannot be alleviated: this company has operated for centuries until recent times, and never went bankrupt. The value of the parameters we estimate, the dividend yield or the risk premium and its term-structure, might thus not be representative. More research and data collection are needed to complement our long time series of dividends and stock prices to be able to obtain more precise estimates of the total return of financial assets over the longue durée. 


\section{Appendix}

\subsection{History of Outstanding Capital}

\begin{tabular}{ccc} 
Period & Number and nature of shares & Reason \\
\hline $1372-1374$ & 80 divisible & Merger of independent mills \\
$1374-1384$ & 88 divisible & Purchase of a mill \\
$1384-1535$ & 96 divisible & Purchase of another mill \\
$1535-1714$ & 100 divisible & Unknown \\
$1714-1804$ & 128 divisible & M. Abeille receives half of the shares \\
$1804-1888$ & 136 divisible & 8 shares are issued to pay for repairs \\
$1888-1910$ & 544 divisible & Split $1: 4$ \\
$1910-1928$ & 6,450 non-divisible & Merger with "Toulousaine d'Electricité" \\
$1928-1943$ & 205,875 non-divisible & Unification of different stocks and split $5: 1$ \\
$1943-1946$ & 319,375 non-divisible & Issue of new shares \\
\hline
\end{tabular}




\subsection{Adjustment for Inflation}

There is considerable research into the question of how best to measure inflation over the very long term. We chose to express dividends and stock prices in kilos of silver because silver was the basis for the French monetary system and the only metal used in the Toulouse mint after 1540. The best feasible alternative is to express the dividends and the stock prices in kilos of wheat. Our results are robust to this alternative way of correcting for inflation. Another attractive way would be to use the hourly wage of a given job but such a series is unfortunately not available in Toulouse over the time period we consider.

A few details are necessary to interpret the silver price series. Before 1803, all shares and wheat prices (except for the very first prices which were sometimes quoted in gold) are quoted in livres tournois, the main unit of account in France during the pre-1803 period. Livres tournois had an official and a market rate of exchange to silver and we use the market rate. Unfortunately, data on the market rate of exchange between livre tournois and silver are only available at a low frequency. For example, we just have seven exchange rates for the period 1372-1533. After 1533, exchange rates are more frequent. We replace missing values by the latest available observation.

After 1803, prices are in franc germinal, which had a fixed conversion rate of 1 livre tournois to 0.9877 franc. Between 1803 and 1876, the value of the franc germinal remains stable in silver thanks to the gold/silver standard $(1$ franc $=5$ grams of silver at 900/1000 thus 4.5 grams of pure silver). After 1876, France adopted the pure gold standard. The price of Gold remained fixed until WWI. We then collect gold market prices on the French market. Between 1877 and 1946, we convert gold into silver using the rate of 15.5 grams of silver for a gram of gold which is the fixed rate established during the silver/gold standard until 1876.

The most problematic periods for adjusting to real values are France's experiments with fiat money. For a brief period in 1719 and 1720, France replaced metallic currency with 
paper money - a decision that was quickly reversed following a monetary crisis. This event seems not to have affected the prices of shares in Toulouse. In the revolutionary period, France again issued paper money: livres-assignats (See White (1995)). This money was used in our data from 1792 to 1797 . We use weekly values of the assignats in silver coins in the Haute-Garonne from Caron (1909).

Our data on the price of silver in monetary units in Toulouse from 1372 to 1946 are displayed in Figure 9. This time series shows that using values in silver helps correct for monetary inflation: there is an increase in the price of silver over time. Also, given the relative stability of the increasing trend in the silver price, it seems unlikely that using values in silver introduces artificial volatility in our dividend and stock price time series.

[Insert Figure 9 here] 


\section{References}

[1] Ang, A., Bekaert, G., 2007. Stock return predictability: Is it there? Review of Financial Studies 20, 651-707.

[2] Annaert, J., Buelens, F., Deloof, M., 2015. Long Run Stock Returns: Evidence from Belgium 1838-2010. Cliometrica 9, 77-95.

[3] Asparouhova, E., Bossaerts, P., Roy, N., Zame, W., 2016. 'Lucas' In The Laboratory. Journal of Finance, 71, 2727-2781.

[4] Barro, R., 2006. Rare disasters and asset markets in the twentieth century. Quarterly Journal of Economics 121, 823-866.

[5] Bessler, A., 1980. Aggregated personalistic beliefs on yields of selected crops estimated using ARIMA processes. American Journal of Agricultural Economics 62, 666-674.

[6] van Binsbergen, Koijen, R., 2010. Predictive Regressions: A Present-Value Approach. Journal of Finance, 65, 1439-1471.

[7] van Binsbergen, J., Brandt, M., Koijen, R., 2012. On the Timing and Pricing of Dividends. American Economic Review 102, 1596-1618.

[8] van Binsbergen, J., Hueskes, W., Koijen R., Vrugt, E., 2013. Equity Yields. Journal of Financial Economics 110, 503-519.

[9] Bollerslev, T., Law, T.H., Tauchen, G., 2008. Risk, jumps, and diversification. Journal of Econometrics, 144, 234-256.

[10] Bonnet, C., 2013. Jean de Bernuy, les moulins du Bazacle et l'espace urbain : stratégies et réseaux à Toulouse, 1500-1555. Unpublished Master thesis. Université Le Mirail, Toulouse. 
[11] Bossaerts, P., Hillion, P., 1999. Implementing statistical criteria to select return forecasting models: what do we learn? Review of Financial Studies 12, 405-28.

[12] le Bris, D., Goetzmann, W. N., Pouget, S., 2015. Modern Introduction. In: Sicard, G., The Origins of Corporations The Mills of Toulouse in the Middle Ages. Yale University Press, New Haven, pp. IX-XXI.

[13] le Bris, D., Goetzmann, W. N., Pouget, S., 2015. The Development of Corporate Governance in Toulouse: 1372-1946. NBER Working Paper No. 21335.

[14] le Bris D., Hautcour, P.-C., 2010. A Challenge to the Triumphant Optimists, A Blue Chips Index for the Paris Stock Exchange (1854-2007). Financial History Review 27, $141-183$.

[15] Campbell, J., Cochrane, J., 1999. By Force of Habit: A Consumption-Based Explanation of Aggregate Stock Market Behavior. Journal of Political Economy 107, 205-251.

[16] Campbell, J., Shiller, R., 1988. The dividend-price ratio and expectations of future dividends and discount factor. Review of Financial Studies 1, 195-228.

[17] Carlos A., Fletcher, E., Neal L., 2012. Share Portfolios and Risk Management in the Early Years of Financial Capitalism: London 1690-1730. CEI Working Paper Series 2012-12.

[18] Caron, P., 1909. Tableaux de dépréciation du papier-monnaie. Imprimerie Nationale, Paris.

[19] Chabot, B., Kurz, C., 2010. Thats Where The Money Was: Foreign Bias and English Investment Abroad, 1866-1907. Economic Journal 120, 1056-1079.

[20] Chen, L., 2009. On the reversal of return and dividend growth predictability: A tale of two periods. Journal of Financial Economics 99, 128-151. 
[21] Chen, L., Da, Z., Priestley, R., 2012. Dividend Smoothing and Predictability. Management Science 58, 1834-1853.

[22] Cochrane, J., 2008. The dog that did not bark: A defense of return predictability. Review of Financial Studies 21, 1533-1575.

[23] Crockett, S., Duffy, J., 2016. An experimental test of the Lucas asset pricing model, Unpublished Working Paper.

[24] Dimson, E., Marsh, P., Staunton, M., 2008. Triumph of the optimists: 101 years of global investment returns. Princeton University Press, Princeton.

[25] Dimson, E., Spaenjers, C., 2011. Ex post: the investment performance of collectible stamps. Journal of Financial Economics 100, 443-458.

[26] Easley, D., Kiefer, N., O’Hara M., Paperman, J., 1996. Liquidity, Information, and Infrequently Traded Stocks. Journal of Finance 51, 1405-1436.

[27] Fama, E. F., French, K. R., 1988. Dividend yields and expected stock returns, Journal of Financial Economics 22, 3-25.

[28] Frêche, G., Frêche, G., 1967. Les prix des grains, des vins et des légumes à Toulouse (1486-1868). PUF, Paris.

[29] Gehrig, T., Fohlin, C., 2006. Trading costs in early securities markets: the case of the Berlin Stock Exchange 1880-1910. Review of Finance 10, 587-612.

[30] Goetzmann, W., 1993. Patterns in three centuries of stock market prices. Journal of Business 66, 249-270.

[31] Goetzmann, W. N., Ibbotson, R. G., Peng, L., 2001. A new historical database for the NYSE 1815 to 1925: Performance and predictability. Journal of Financial Markets 4, $1-32$. 
[32] Goetzmann, W. N., Ibbotson R. G., 2006. The Equity Risk Premium: Essays and Explorations. Oxford University Press, Oxford.

[33] Goetzmann, W. N., Jorion, P., 1993. Testing the Predictive Power of Dividend Yields. Journal of Finance 48, 663-679.

[34] Goetzmann, W. N., Jorion, P., 1995. A longer look at dividend yields. Journal of Business $68,483-508$.

[35] Goetzmann, W. N., Pouget, S., 2011. A shareholder lawsuit in fourteenth century Toulouse. In: Koppell, J. (Ed.), Origins of Shareholder Advocacy. Palgrave-MacMillan, New-York, pp. 215-229.

[36] Golez, B., Koudijs, P., 2014. Four centuries of return predictability. NBER working paper No. 20814.

[37] Goyal, A., Welch, I., 2003. Predicting the equity premium with dividend ratios. Management Science 49, 639-54.

[38] Goyal, A., Welch, I., 2006. A comprehensive look at the empirical performance of the equity premium prediction. Review of Financial Studies 21, 1455-1508.

[39] Hoffman, P.T., Postel-Vinay, G., Rosenthal, J.-L., 2000. Priceless markets, the political economy of credit in Paris, 1660-1870. University of Chicago Press, Chicago.

[40] Homer, S., Sylla, R., 2005. A History of Interest Rates, Fourth Edition. Wiley, Newyork.

[41] Jung, J., Shiller, R., 2005. Samuelson's dictum and the stock market. Economic Inquiry 43, 221-228.

[42] Julliard, C., Gosh, A., 2012. Can Rare Events Explain the Equity Premium Puzzle? Review of Financial Studies 25, 3037-3076. 
[43] Koudijs, P., 2016. The boats that did not sail: asset price volatility and market efficiciency in a natural experiment. Journal of Finance 71, 1185-1226.

[44] Leroy, S., Porter, R., 1981. The present-value relation: tests based on implied variance bounds. Econometrica 49, 555-574.

[45] Lettau, M., Ludvigson, S., 2001. Resurrecting the (C)CAPM: A Cross-Sectional Test When Risk Premia Are Time-Varying. Journal of Political Economy 109, 1238-1287.

[46] Lettau, M., Wachter, J., 2007. Why Is Long-Horizon Equity Less Risky? A DurationBased Explanation of the Value Premium. Journal of Finance 62, 55-92.

[47] Lewellen, J., 2004. Predicting returns with financial ratios. Journal of Financial Economics 74, 209-235.

[48] Menzly, L., Santos T., Veronesi, P., 2004. Understanding predictability. Journal of Political Economy 112, 1-47.

[49] Pagan, A., 1984. Econometric Issues in the Analysis of Regressions with Generated Regressors. International Economic Review 25, 221-247.

[50] Pástor, L., Stambaugh, R. F., 2009. Predictive systems: Living with imperfect predictors. Journal of Finance 64, 1583-1628.

[51] Reinhart, C., Rogoff, K., 2014. This Time Is Different: A Panoramic View of Eight Centuries of Financial Crises. Annals of Economics and Finance 15, 1065-1188.

[52] Rietz, T. A., 1988. The equity risk premium: a solution. Journal of Monetary Economics $22,117-131$.

[53] Saboly, M., 2001. L'analyse d'une crise: les Moulins du Bazacle, une étude de cas moderne? Entreprises et Histoire 27, 70-88. 
[54] Shiller, R. J., 1981. The Use of Volatility Measures in Assessing Market Efficiency. Journal of Finance, 36: 291304.

[55] Schwert, G., 1990. Stock market volatility. Financial Analysts Journal 46, 23-34.

[56] Sicard, G., 1953. Aux origines des sociétés anonymes. Les moulins de Toulouse au Moyen Age. Armand Colin, Paris.

[57] Siegel, J., 2007. Stocks for the Long Run, Fourth Edition. McGraw-Hill, New-York.

[58] Stambaugh, R.F., 1999. Predictive regressions. Journal of Financial Economics 54, 375421.

[59] Tauchen, G., Zhou, H., 2011. Realized jumps on financial markets and predicting credit spreads. Journal of Econometrics 160, 102-118.

[60] Vuolteenaho, T., 2002. What drives firm-level stock returns? Journal of Finance 57, $233-264$.

[61] West, K., 1988. Bubbles, Fads and Stock Price Volatility Tests: A Partial Evaluation. Journal of Finance 43, 639-656.

[62] White, E., 1995. The French Revolution and the Politics of Government Finance, 17701815. Journal of Economic History 55, 227-255.

[63] Wolff, P., 1954. Commerce et marchands de Toulouse, v.1350-v.1450. Plon, Paris.

[64] Yang, S-R., Koo, W., Wilson, W., 1992. Heteroskedasticity in Crop Yield Models. Journal of Agricultural and Resource Economics 17, 103-109. 


\section{Table 1: Summary statistics}

Table 1 reports summary statistics about the annual returns on Bazacle shares. Statistics are computed using the price closest to the end of each calendar year. We use data in grams of silver. Prices and dividends are missing for some years. For the dividend yield, we require the dividend from the current year and a price from the previous year. For capital gains returns, we only use years for which prior and current year prices exist. We do the same to compute price changes which represent the difference between current and prior share prices. We present statistics for the full sample as well as for various sub-periods, the Middle-Ages from 1372 up to 1531 (for which we do not have a lot of data), the milling activity period from 1532 to 1888 (for which we have plenty of data), and the electricity period from 1889 up to 1946.

\section{Dividend Yield Capital Gain Price Change}

\begin{tabular}{|c|c|c|c|c|c|c|}
\hline \multirow[b]{2}{*}{ Data in Silver } & \multicolumn{2}{|c|}{ (in \%) } & \multicolumn{2}{|c|}{ (in \%) } & \multicolumn{2}{|c|}{ (in grams of silver) } \\
\hline & Mean & St. Dev. & Mean & St. Dev. & Mean & St. Dev. \\
\hline $1372-1946$ & $5.16 \%$ & $7.55 \%$ & $15.48 \%$ & $122.36 \%$ & 30.72 & 6697 \\
\hline Obs. (p-value) & 327 & $(0.00)$ & 295 & $(0.03)$ & 295 & $(0.94)$ \\
\hline \multirow[t]{2}{*}{$1372-1531$} & $4.94 \%$ & $6.11 \%$ & $-2.70 \%$ & $36.68 \%$ & -271.48 & 1168 \\
\hline & 3 & $(0.16)$ & 11 & $(0.81)$ & 11 & $(0.44)$ \\
\hline \multirow[t]{2}{*}{$1532-1888$} & $5.14 \%$ & $8.16 \%$ & $18.44 \%$ & $134.86 \%$ & 75.25 & 6366 \\
\hline & 270 & $(0.00)$ & 232 & $(0.04)$ & 232 & $(0.86)$ \\
\hline \multirow[t]{2}{*}{ 1889-1946 } & $5.29 \%$ & $3.34 \%$ & $6.13 \%$ & $58.86 \%$ & -104.05 & 8640 \\
\hline & 54 & $(0.00)$ & 52 & $(0.45)$ & 52 & $(0.93)$ \\
\hline
\end{tabular}


Table 2: Phillips-Perron unit root tests on dividends and stock prices

Table 2 reports the p-values of Phillips-Perron unit root tests for the dividend and stock price processes. The null hypothesis is that the processes have a unit root. A small p-value indicates that the null hypothesis of non-stationarity can be rejected. The Dickey-Fuller statistics are also provided.

\begin{tabular}{ccccc} 
& \multicolumn{2}{c}{ Dividend process } & \multicolumn{2}{c}{ Stock price process } \\
\cline { 2 - 5 } & Dickey-Fuller & p-value & Dickey-Fuller & p-value \\
\hline \hline $\mathbf{1 4 4 1 - 1 9 4 6}$ & -11.95 & 0.01 & -6.23 & 0.01 \\
$\mathbf{1 5 3 2 - 1 9 4 6}$ & -11.26 & 0.01 & -6.26 & 0.01 \\
$\mathbf{1 5 3 2 - 1 8 8 8}$ & -10.98 & 0.01 & -6.23 & 0.01 \\
$\mathbf{1 5 3 2 - 1 8 1 5}$ & -10.91 & 0.01 & -6.84 & 0.01 \\
\hline
\end{tabular}


Table 3: Dividend process estimation

Table 3 reports the estimation of an $\operatorname{ARMA}(1,1)$ model applied to the dividend process. The estimated equation is: $D_{t+1}=\alpha+\beta D_{t}+\gamma \epsilon_{t}^{D}+\epsilon_{t+1}^{D}$, with $D_{t}$ being the dividend distributed during year $t$. We assume that $\mathbb{E}\left(\epsilon_{t+1}^{D}\right)=\mathbb{E}_{t}\left(\epsilon_{t+1}^{D}\right)=0$. We fit the model via Maximum Likelihood.

\begin{tabular}{ccccccc} 
Period & $\alpha$ & p-val & $\beta$ & p-val & $\gamma$ & p-val \\
\hline \hline $\mathbf{1 4 4 1 - 1 9 4 6}$ & 181 & 0.00 & 0.80 & 0.00 & -0.35 & 0.00 \\
$\mathbf{1 5 3 2 - 1 9 4 6}$ & 229 & 0.00 & 0.77 & 0.00 & -0.32 & 0.00 \\
$\mathbf{1 5 3 2 - 1 8 8 8}$ & 214 & 0.00 & 0.77 & 0.00 & -0.35 & 0.00 \\
$\mathbf{1 5 3 2 - 1 8 1 5}$ & 144 & 0.00 & 0.84 & 0.00 & -0.38 & 0.00 \\
\hline
\end{tabular}

Table 4: Estimation of the asset pricing equation

Table 4 reports maximum likelihood estimations of GLS regressions representing the pricing equation: $P_{t}=$ $a+b D_{t}+c \epsilon_{t}^{D}+\epsilon_{t}^{P} . D_{t}$ and $\epsilon_{t}^{D}$ are the dividend and the dividend shock during year $t$, respectively. The residual $\epsilon_{t}^{P}$ captures the risk correction and is assumed to follow an $\mathrm{AR}(1)$ process with an autoregressive parameter $\delta$. The pseudo- $R^{2}$ represents the proportion of price volatility associated with variation in dividends and dividend shocks and is equal to: $\frac{b^{2} \operatorname{Var}\left(D_{t}\right)+c^{2} \operatorname{Var}\left(\epsilon_{t}^{D}\right)}{\operatorname{Var}\left(P_{t}\right)}$.

\begin{tabular}{cccccccccc} 
Period & $a$ & $\mathrm{p}$-val & $b$ & $\mathrm{p}$-val & $c$ & $\mathrm{p}$-val & pseudo- $R^{2}$ & $\delta$ & $\mathrm{p}$-val \\
\hline \hline $\mathbf{1 4 4 1 - 1 9 4 6}$ & 14,682 & 0.00 & 3.90 & 0.00 & -1.84 & 0.01 & $15 \%$ & 0.81 & 0.00 \\
$\mathbf{1 5 3 2 - 1 9 4 6}$ & 15,295 & 0.00 & 4.09 & 0.00 & -1.96 & 0.01 & $17 \%$ & 0.77 & 0.00 \\
$\mathbf{1 5 3 2 - 1 8 8 8}$ & 14,356 & 0.00 & 4.71 & 0.00 & -2.45 & 0.01 & $24 \%$ & 0.77 & 0.00 \\
$\mathbf{1 5 3 2 - 1 8 1 5}$ & 12,217 & 0.00 & 6.59 & 0.00 & -3.51 & 0.00 & $43 \%$ & 0.76 & 0.00 \\
\hline
\end{tabular}


Table 5: Testing the model

Table 5 reports, for the two quantitative theoretical predictions of our model, Equations (5.11) and (5.12), the bounds of the $95 \%$ confidence intervals for the left-hand side of the equations, as well as the p-values at which the model is rejected. The model is rejected with a p-value of $5 \%$ if zero is not part of the $95 \%$ confidence interval. The two theoretical predictions are related to the fact that prices should reflect the conditional expectation of future dividends, Equation (5.11), and to the fact that the average price should reflect the average level of dividends, Equation (5.12). The confidence intervals and p-values are based on standard errors computed with the delta method.

\begin{tabular}{cccccccc} 
& \multicolumn{3}{c}{ Equation (5.11) } & & \multicolumn{3}{c}{ Equation (5.12) } \\
\cline { 2 - 4 } Period & lower bound & higher bound & p-val reject & & lower bound & higher bound & p-val reject \\
\hline $\mathbf{1 4 4 1 - 1 9 4 6}$ & -0.073 & 0.108 & 0.71 & & -683 & 598 & 0.90 \\
$\mathbf{1 5 3 2 - 1 9 4 6}$ & -0.064 & 0.109 & 0.61 & & -664 & 568 & 0.88 \\
$\mathbf{1 5 3 2 - 1 8 8 8}$ & -0.049 & 0.086 & 0.60 & & -616 & 562 & 0.93 \\
$\mathbf{1 5 3 2 - 1 8 1 5}$ & -0.030 & 0.068 & 0.46 & & -535 & 476 & 0.91 \\
\hline
\end{tabular}




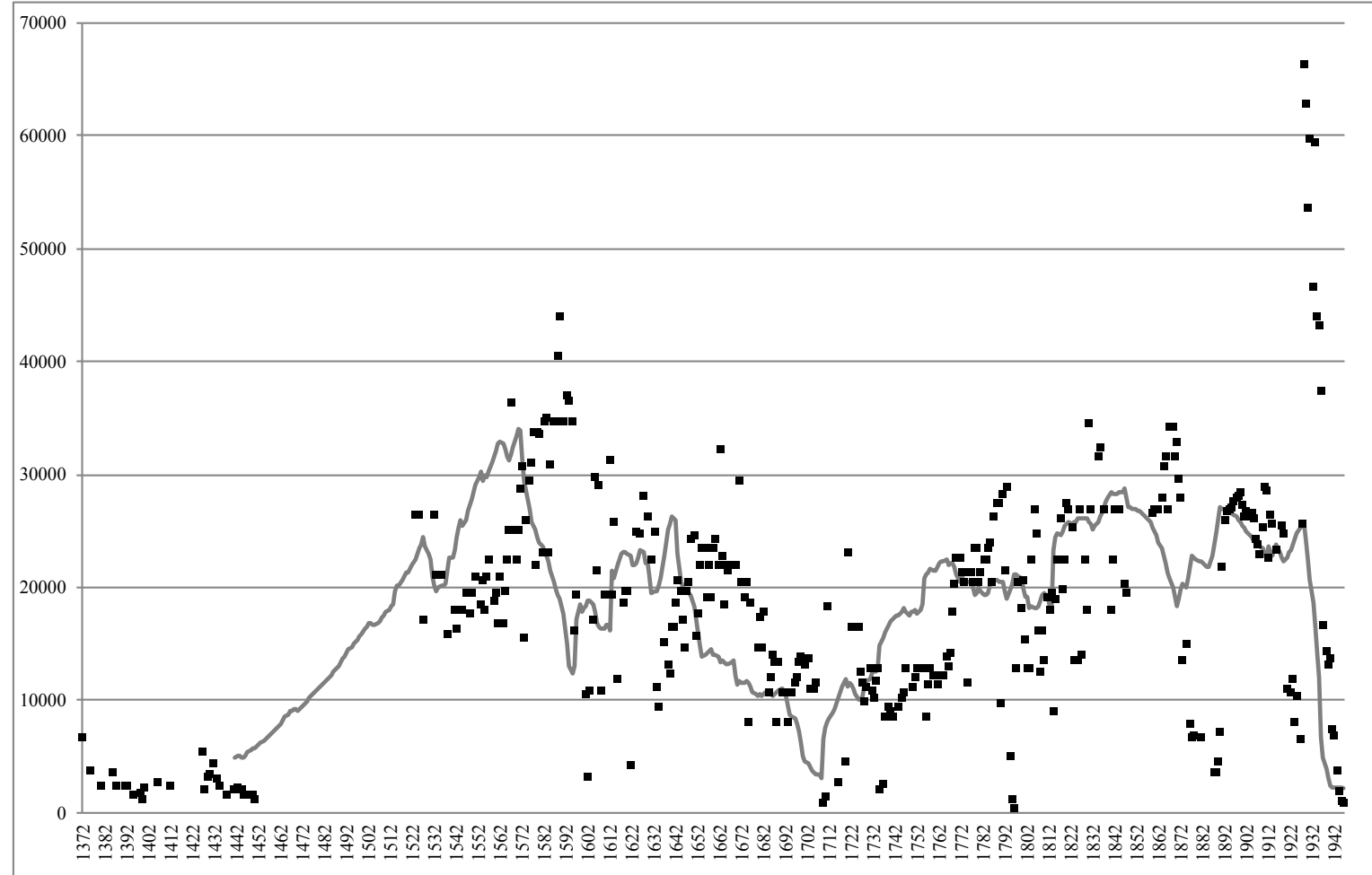

Figure 1: Bazacle company's stock price and present value of subsequent realized dividends (in kilograms of silver).

This Figure proposes a Shiller (1981)'s type of graph that shows the actual stock price of the Bazacle company (black dots) and the present value of subsequent dividends assuming a fixed $5 \%$ discount rate and perfect foresight (grey line). The stock price series begins in 1372. The present value of subsequent realized dividends is computed from 1441 onward, the first year in which we have both a stock price and a dividend. For a given year after 1441, a missing dividend is replaced by the average dividend over the past 30 years. At the end of the period, we assume that dividends are null even if, in fact, after the 1946 nationalization, investors received some small payments. The rate of $5 \%$ corresponds to the legal rate of interest under the Roman law applicable in Toulouse up to the French revolution. 


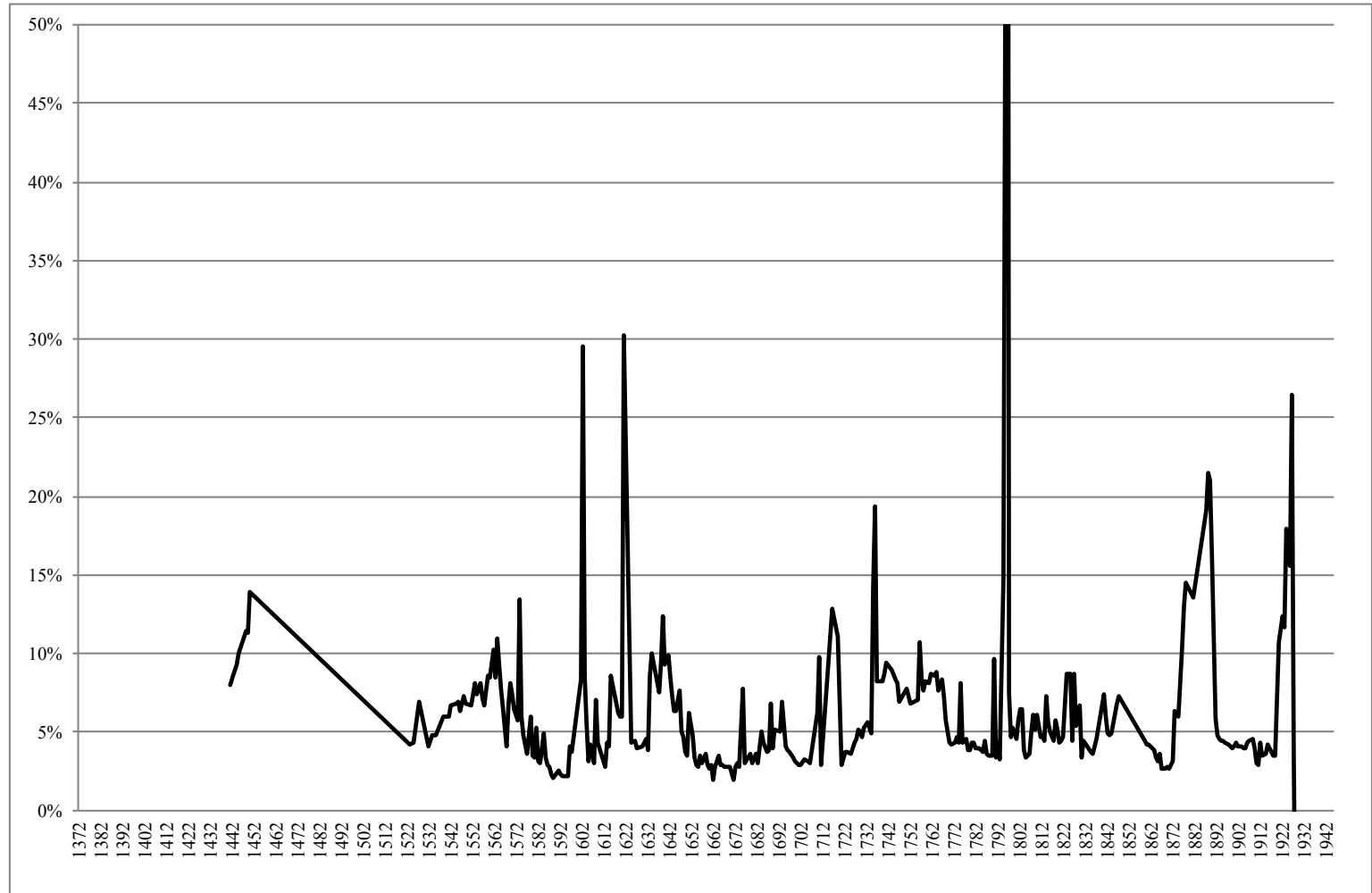

Figure 2: Implied discount rate given observed prices and perfect dividend forecasts.

This Figure depicts the implied discount rates that equalizes observed prices and the discounted values of future dividends assuming perfect foresight. We start our estimation of the implied rate in 1441, the first year with both a price and a dividend. A missing dividend is replaced by the average dividend observed over the past 30 years. There is a pick in the series (not represented) at the time of the French revolution due to France's experimentation with fiat money. At the end of the period, the series is negative (not represented) to equalize stock prices to the discounted value of the future dividends that is close to zero due to the post-WWII nationalization. 


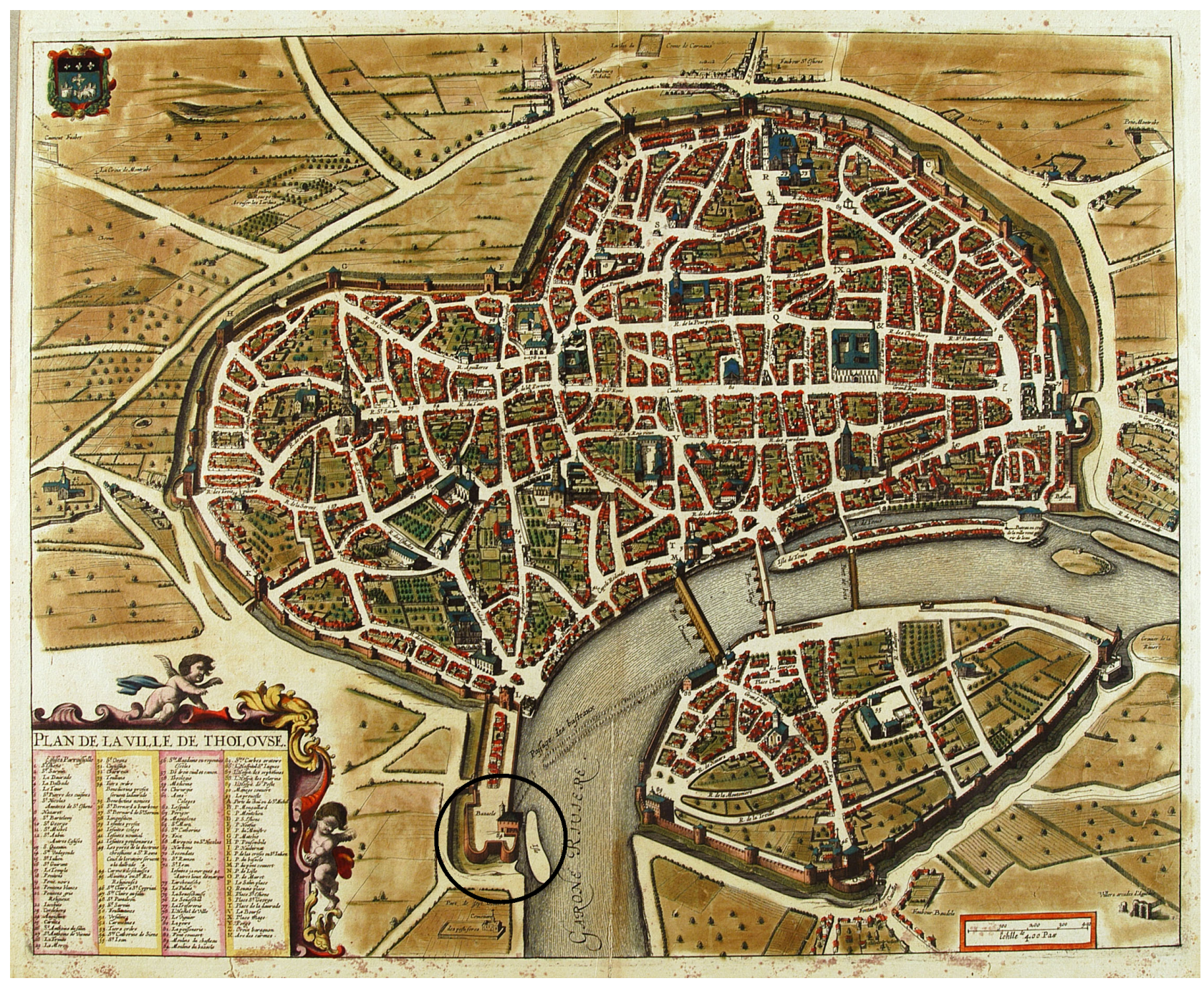

Figure 3: Bazacle company's location in Toulouse on the river Garonne.

This Figure shows a map of Toulouse by Melchior Tavernier dating from 1631 (the top of the map is the east). The location of the Bazacle company is shown by a circle at the bottom of the map. The Bazacle mills' dam is also visible. 


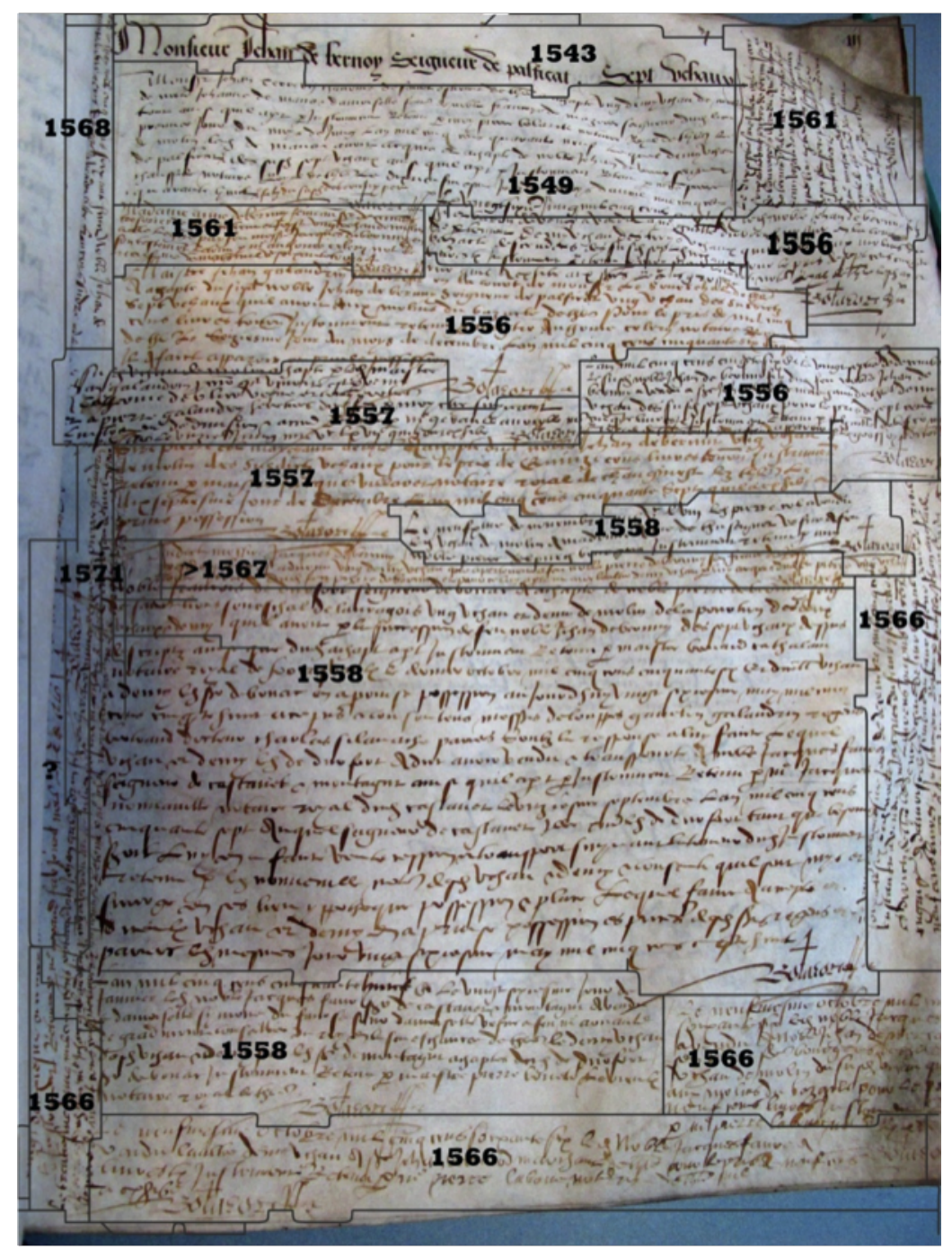

Figure 4: A register of shareholders from 1532.

This Figure shows an example of register of shareholders from 1532. The shareholder is Jean de Bernuy, a rich pastel merchant from Toulouse. Various transactions are written at different points in time reflecting the various times at which Jean de Bernuy or his heirs have sold their shares. The original document is available at the "Archives Départementales de la Haute-Garonne" in Toulouse. This picture is taken from Bonnet (2013). 


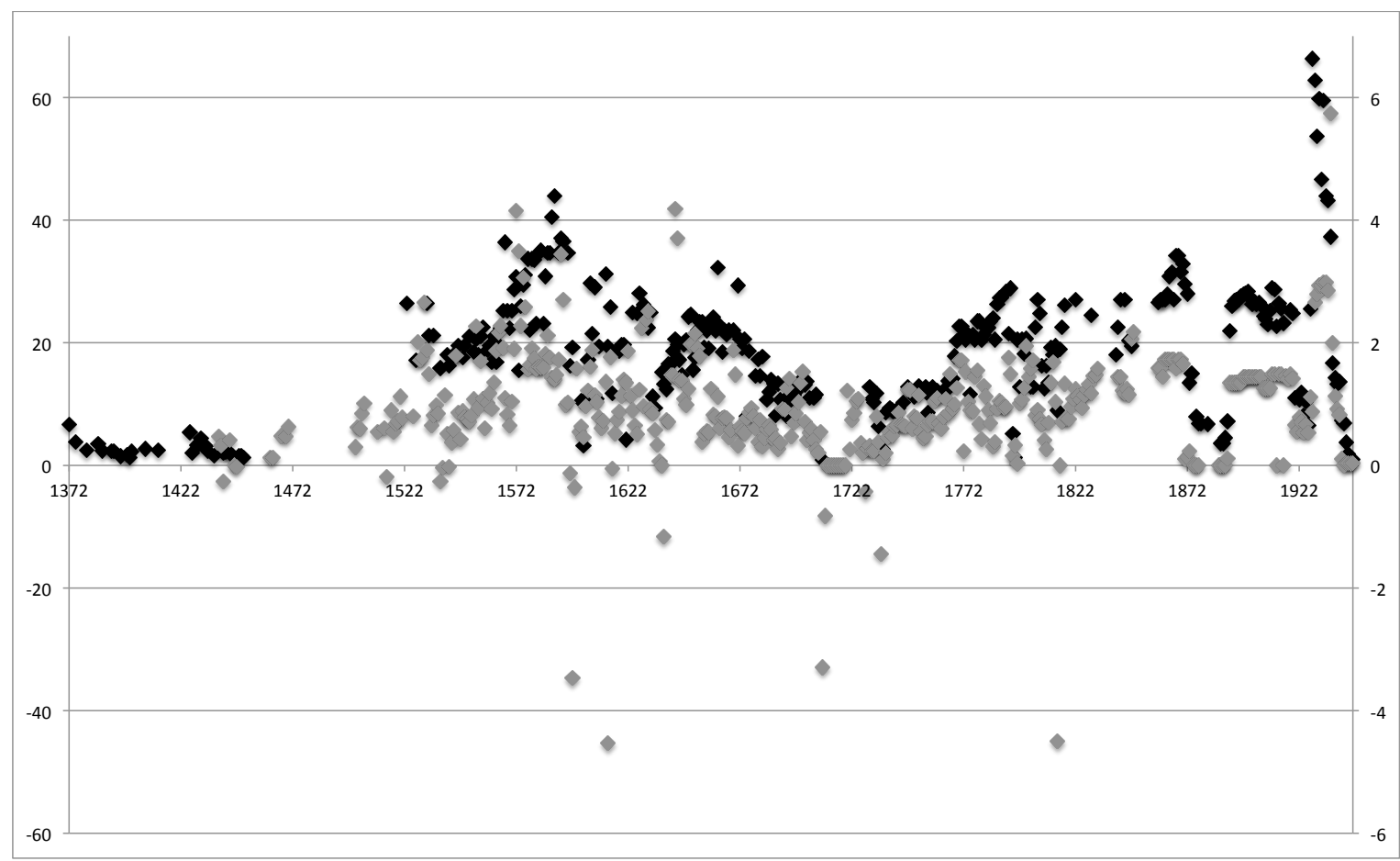

Figure 5: Bazacle share prices and dividends from 1372 to 1946 (in kilograms of silver).

This Figure shows Bazacle company's end-of-year share price and dividend from 1372 to 1946. Missing data before 1532 are due to lack of information. Data are in kilograms of silver to control for monetary inflation. The left axis is for share prices (in black), the right one for dividends (in grey). 


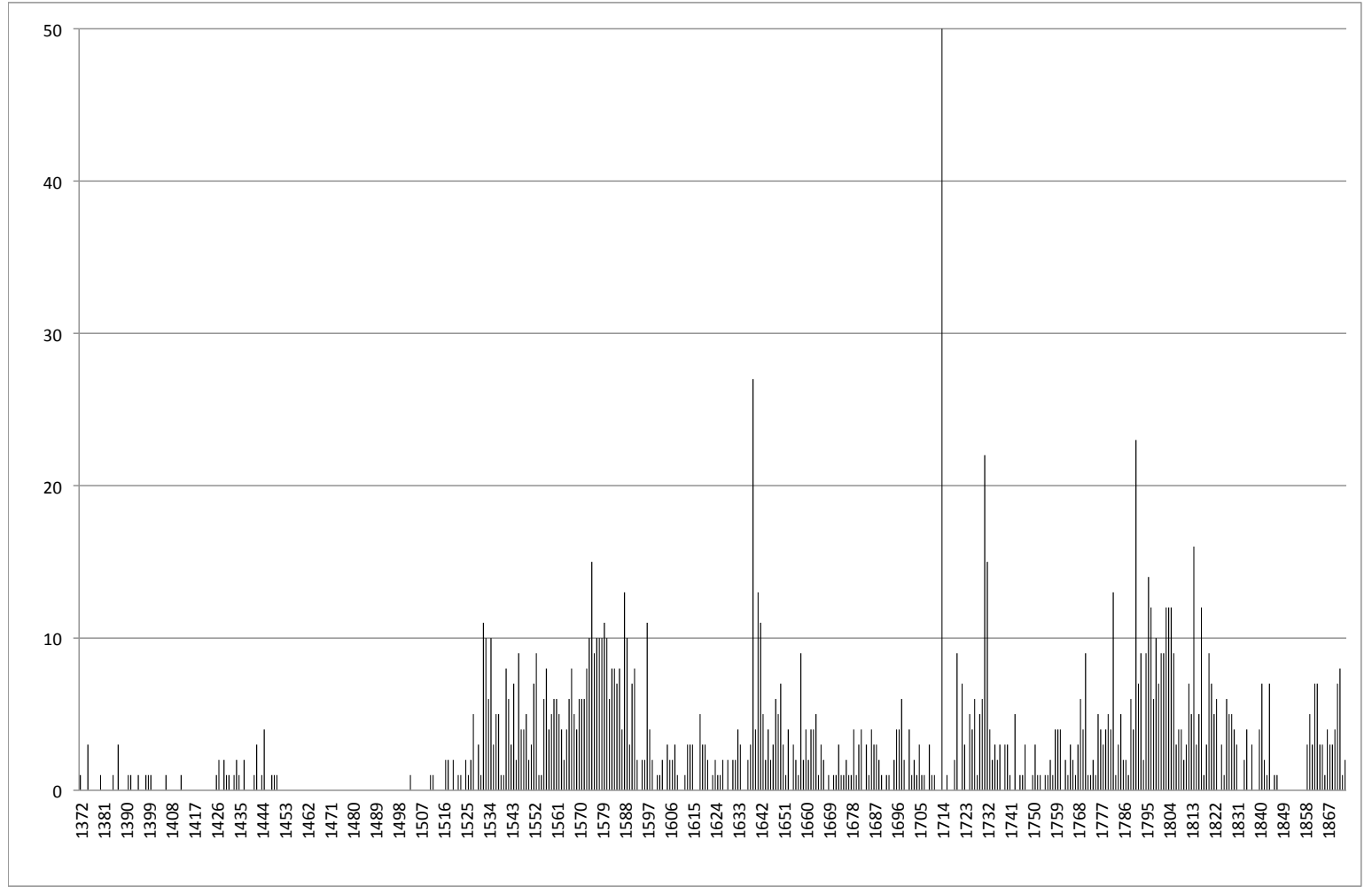

Figure 6: Number of transactions per year from 1372 to 1888 (in shares).

This Figure shows the number of share transaction for the Bazacle company from 1372 to 1888, the grain milling period of the Bazacle company. Missing data before 1532 are due to lack of information. 


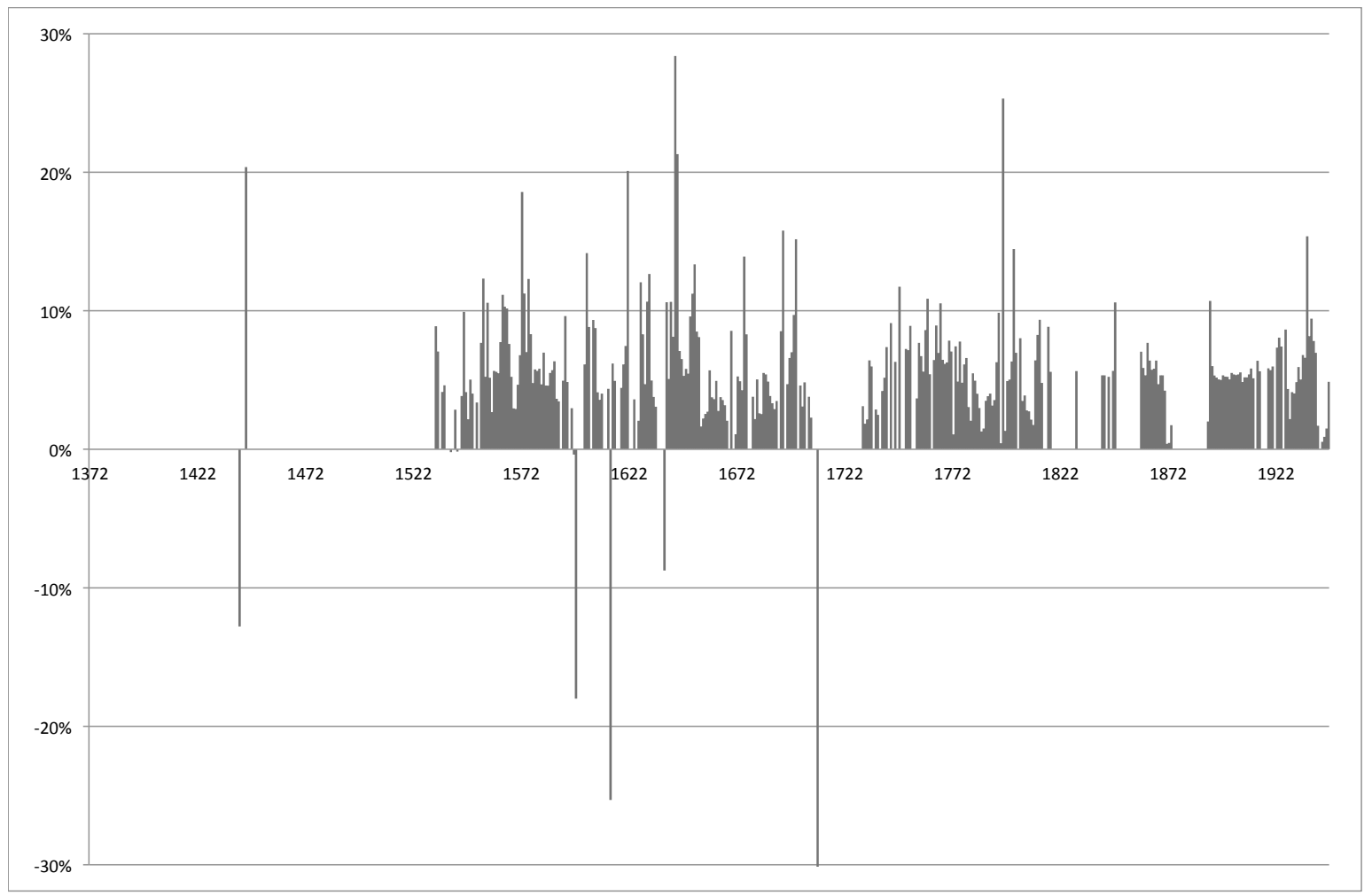

Figure 7: Dividend yield from 1372 to 1946.

This Figure shows the dividend yield. For an observation to be recorded, we require the dividend from the current year and a price from the previous year to be available. Price and dividend data used to compute the dividend yield are in kilograms of silver. 


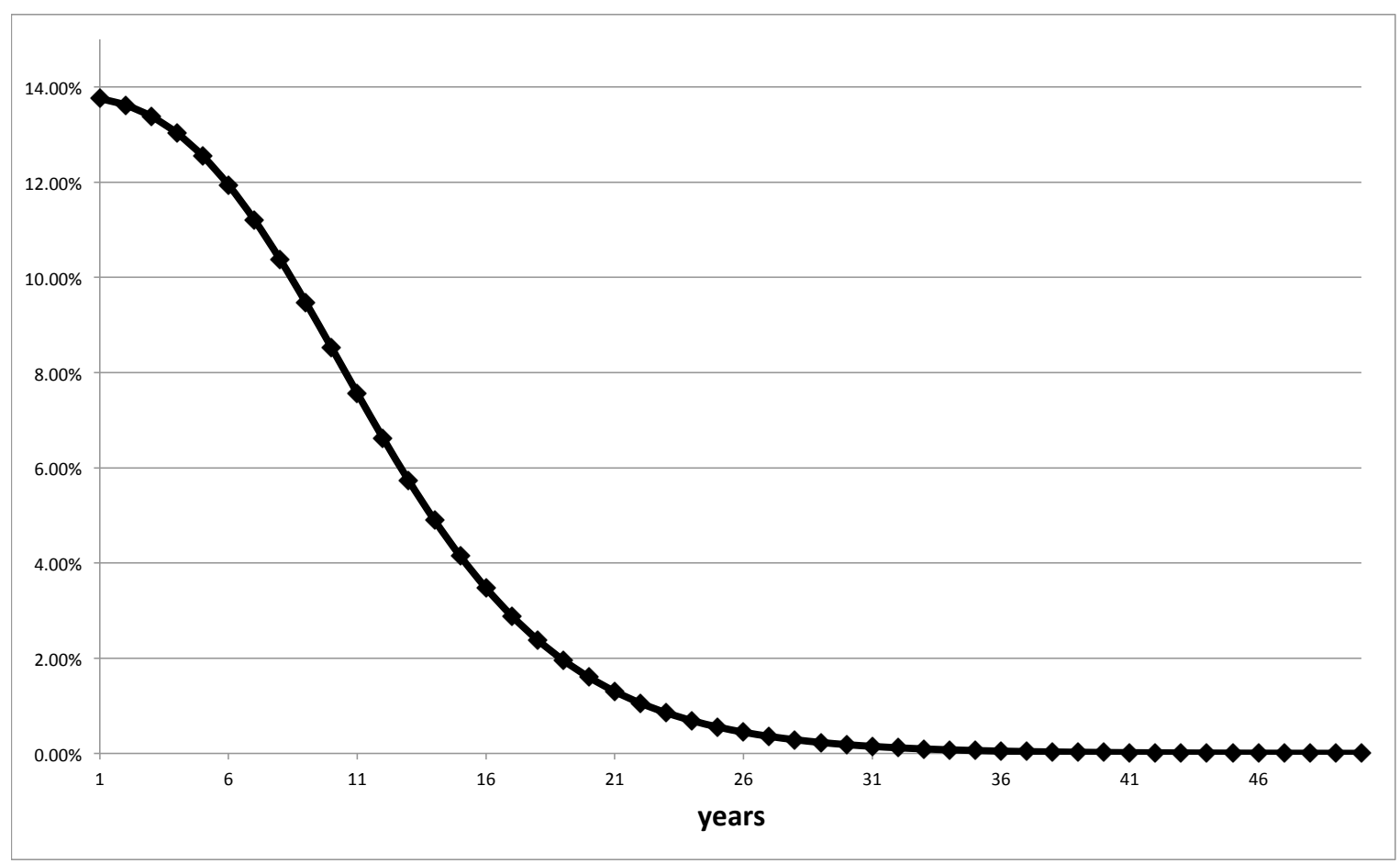

Figure 8: Term structure of the risk premium.

This Figure shows the term structure of the risk premium for the parameters estimated over the full 1441-1946 period. 


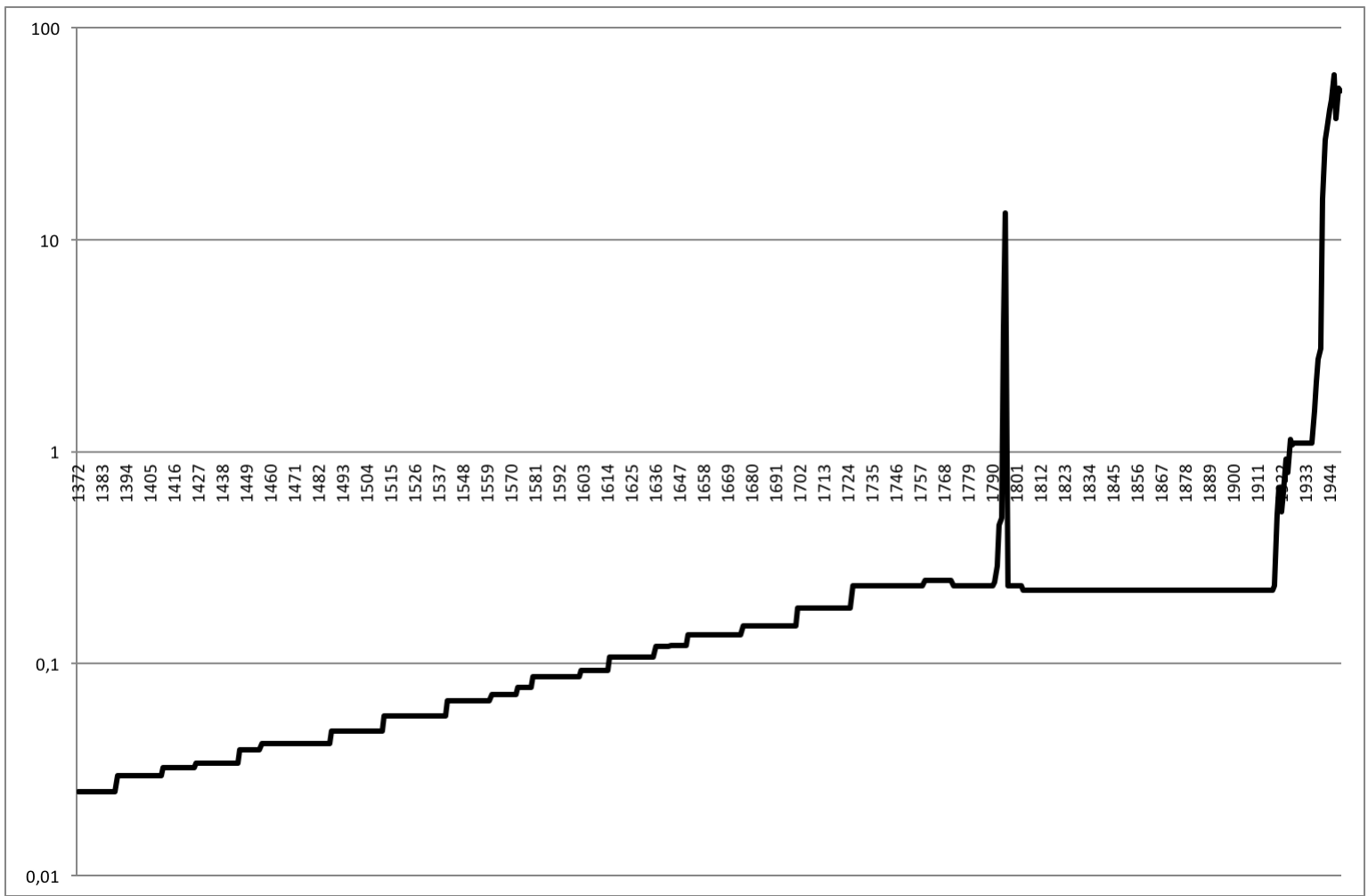

Figure 9: Price of silver in current monetary units in Toulouse from 1372 to 1946.

This Figure displays the price of one gram of silver in current monetary units (log scale), i.e., livres tournois from 1372 to 1803 (except during the revolutionary period in which assignats were used from 1792 to 1797), and francs from 1804 to 1946 . Francs were convertible, at a fixed rate, in silver and gold from 1804 to 1876 (implying a fixed rate of conversion of 15.5 grams of silver per gram of gold) and then in gold only from 1877 to 1914. Since 1877, our reference is the market price of gold and we use the 15.5 silver/gold ratio in order to obtain values in silver. 